HAAS, J., PELIKÁN, P., GÖRÖG, Á., JÓZSA, S., OZSVÁRT, P. 2013. Stratigraphy, facies and geodynamic settings of Jurassic formations in the Bükk Mountains, North Hungary: its relations with the other areas of the Neotethyan realm.

Geological Magazine 150(1): 18-49.

doi: $10.1017 /$ S0016756812000246

This is MTA-MTM-ELTE Paleo contribution No. 102. 
Additional services for Geological Magazine:

Email alerts: $\underline{\text { Click here }}$

Subscriptions: $\underline{\text { Click here }}$

Commercial reprints: Click here

Terms of use : $\underline{\text { Click here }}$

Stratigraphy, facies and geodynamic settings of Jurassic formations in the Bükk Mountains, North Hungary: its relations with the other areas of the Neotethyan realm

JÁNOS HAAS, PÁL PELIKÁN, ÁGNES GÖRÖG, SÁNDOR JÓZSA and PÉTER OZSVÁRT

Geological Magazine / FirstView Article / January 2006, pp 1 - 32

DOI: 10.1017/S0016756812000246, Published online: 12 June 2012

Link to this article: http://journals.cambridge.org/abstract S0016756812000246

How to cite this article:

JÁNOS HAAS, PÁL PELIKÁN, ÁGNES GÖRÖG, SÁNDOR JÓZSA and PÉTER OZSVÁRT Stratigraphy, facies and geodynamic settings of Jurassic formations in the Bükk Mountains, North Hungary: its relations with the other areas of the Neotethyan realm. Geological Magazine, Available on CJO 2012 doi:10.1017/S0016756812000246

Request Permissions : $\underline{\text { Click here }}$ 


\title{
Stratigraphy, facies and geodynamic settings of Jurassic formations in the Bükk Mountains, North Hungary: its relations with the other areas of the Neotethyan realm
}

\author{
JÁNOS HAAS*, PÁL PELIKÁN $\ddagger$, ÁGNES GÖRÖG§†, SÁNDOR JÓZSAq \\ \& PÉTER OZSVÁRT\| \\ ${ }^{*}$ Geological, Geophysical and Space Science Research Group, Hungarian Academy of Sciences, \\ Pázmány Péter sétány 1/C, H-1117 Budapest, Hungary \\ $\ddagger$ Geological Institute of Hungary, Stefánia út 14, H-1143 Budapest \\ §Department of Palaeontology, Eötvös Loránd University, Pázmány Péter sétány 1/C, H-1117 Budapest, Hungary \\ ФDepartment of Petrology and Geochemistry, Eötvös Loránd University, Pázmány Péter sétány \\ 1/C, H-1117 Budapest, Hungary \\ \|Research Group for Palaeontology, Hungarian Academy of Sciences-Hungarian Natural History Museum, \\ P. O. Box 137, H-1431 Budapest, Hungary
}

(Received 22 April 2011; accepted 23 March 2012)

\begin{abstract}
Jurassic mélange complexes related to the subduction of the Neotethys Ocean occur in the Bükk Mountains, North Hungary. This paper characterizes the sedimentary sequence of basin and slope facies that occur in the southwestern part of the Bükk Mountains, placing special emphasis on the redeposited sedimentary rocks (olistostromes, olistoliths: Mónosbél Group) in order to obtain information on the provenance of the clasts, and the mode and time of their redeposition. The series of formations studied shows a general coarsening-upwards trend. Based on radiolarians and foraminifera, the Mónosbél Group formed in Early to Late Bathonian time. The lower part of the complex is typified by a predominance of pelagic carbonates, shale and radiolarite with andesitic volcaniclastic intercalations. The higher part of the succession is characterized by polymictic olistostromes. Large olistoliths that are predominantly blocks of Bathonian shallow marine limestone (Bükkzsérc Limestone) appear in the upper part of the sequence. Based on the biostratigraphic and sedimentological data, results of analyses of the redeposited clasts and taking into consideration the concepts of the development of the western Neotethys domain, the evolutionary stages of the sedimentary basins were defined. The onset of the compressional stage led to initiation of nappe stacking that led to the formation of polymict olistostromes and then to the redeposition of large blocks derived from out-of-sequence nappes of the former platform foreland.
\end{abstract}

Keywords: gravity deposits, polymictic olistostrome, subduction, Neotethys, biostratigraphy, foraminifera, radiolaria.

\section{Introduction}

The Jurassic sedimentary and volcanic formations occurring in the southwestern part of the Bükk Mountains were only recognized at the beginning of the 1980s (Bérczi-Makk \& Pelikán, 1984; Balogh, Kozur \& Pelikán, 1984; Csontos, Bérczi-Makk \& Thiebault, 1991; Csontos, Dosztály \& Pelikán, 1991). This recognition significantly changed the previous concepts concerning the stratigraphy, structure and evolutionary history of the Bükk Mountains, and led to the elaboration of a new structural model.

The striking similarity of the Upper Palaeozoic and Triassic formations of the Bükk Mountains with the corresponding formations of the Dinarides has been known for a long time (Schréter, 1959; Balogh, 1964; Protić et al. 2000; Pamić, Tomljenović \& Balen, 2002; Filipović et al. 2003). Studies in the last

$\dagger$ †uthor for correspondence: gorog@ludens.elte.hu decades pointed out similarities between the Jurassic olistostromal sedimentary and volcanic complexes in the Bükk Mountains, and the ophiolite mélange complex of the Dinarides (e.g. Pamić, 1997, 2003; Haas \& Kovács, 2001; Dimitrijević et al. 2003; Haas et al. 2006, 2011). These considerations inspired the concept that the Bükk Unit was derived from the Dinaridic realm and was emplaced in its present-day setting via large-scale transpressive tectonic displacements in the Tertiary Period (e.g. Csontos et al. 1992; Csontos \& Nagymarosy, 1998; Haas \& Kovács, 2001; Csontos \& Vörös, 2004; Schmid et al. 2008).

The aim of the present paper is to characterize the Jurassic formations of the study area in the southwestern part of the Bükk Mountains with special regard to the redeposited sedimentary rocks (olistostromes) in order to obtain information on the provenance of the clasts, as well as on the mode and time of their redeposition. Determining the succession of the complex redeposition processes may contribute to 


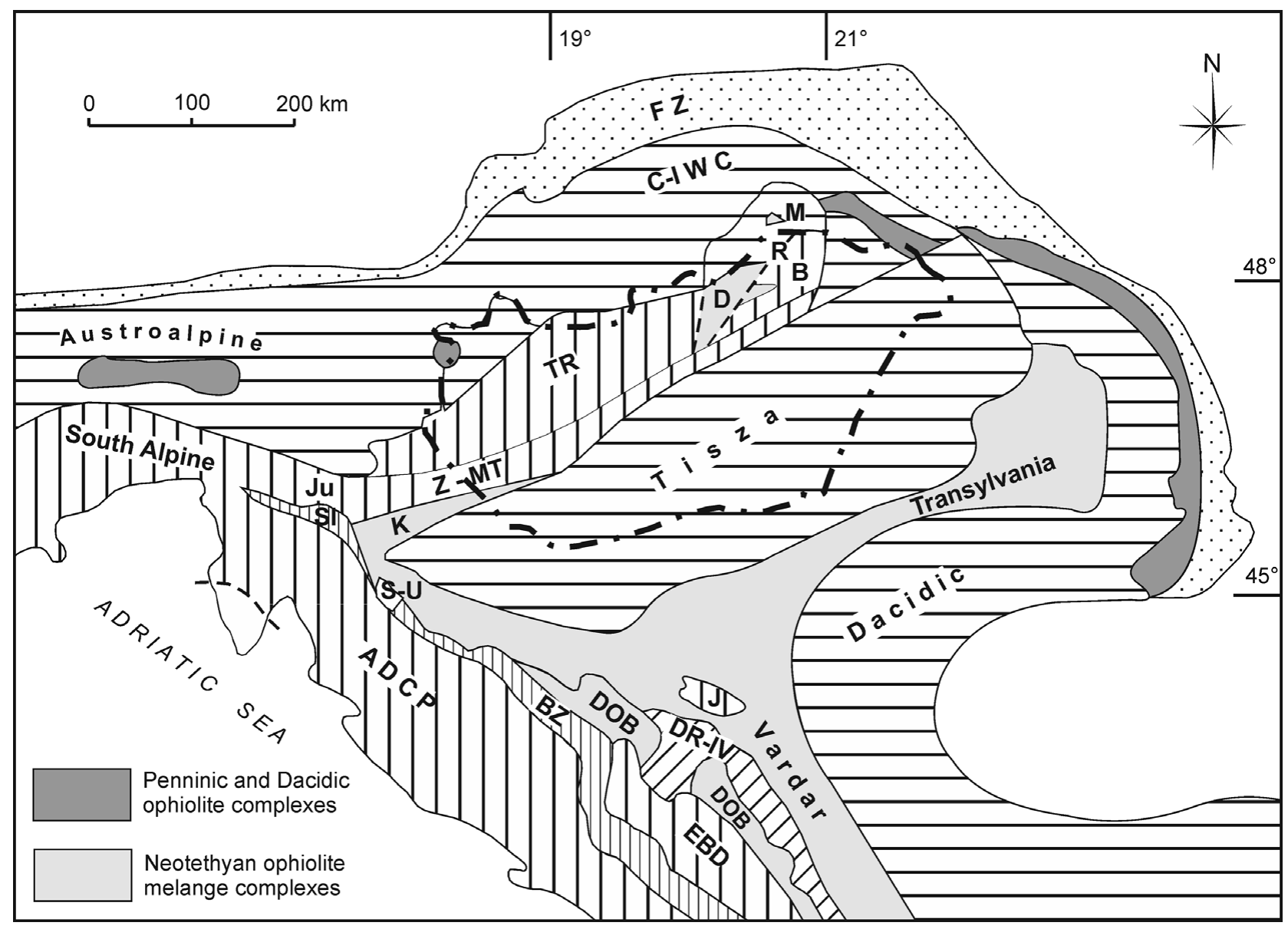

Figure 1. Geographic and geologic setting of the Bükk Unit within the Circum-Pannonian region. Abbreviations: ADCP - AdriaticDinaridic Carbonate Platform; B - Bükk Unit; BZ - Bosnian Zone; C-I WC - Central and Inner West Carpathians; D - Darnó Unit; DOB - Dinaridic Ophiolite Belt; DR-IV - Drina-Ivanica Unit; EBD - East Bosnian-Durmitor Unit; FZ - Helvetic and Outer Carpathian Flysch Zone; J - Jadar Block; Ju - Julian Alps; K - Kalnik Unit; M - Meliata Unit; R - Rudabánya; Sl - Slovenian Trough; S-U - Sana-Una Unit; TR - Transdanubian Range Unit; Z-MT - Zagorje-Mid-Transdanubian Unit. Vertical lines - units of Adriatic Microplate origin; horizontal lines - units of European Plate origin.

understanding the history of closure of the western Neotethys Ocean, which places this study within a much wider context.

\section{Geologic setting}

The area of the present study is located in the southwestern part of the Bükk Mountains (Figs 1, 2). The eastern part of the study area is made up of Middle to Upper Triassic (Ladinian to Norian) platform limestone and grey cherty limestone of intraplatform basin facies, with intercalations of basalt (Velledits, 2000; Pelikán \& Dosztály, 2000; Pelikán, 2005) (Fig. 3). These are overlain by red radiolarian chert (Bányahegy Radiolarite Formation) in a thickness of about $30 \mathrm{~m}$ (Figs 3, 4). Based on investigations of poorly preserved radiolarians taken from several sections, Dosztály (in Csontos, Dosztály \& Pelikán, 1991) assigned this formation to the Callovian-Oxfordian time period.

The red chert formation is overlain by a dark grey to black shale succession consisting of sandstone, siltstone and claystone layers (Lökvölgy Formation). The succession is made up of millimetre-scale graded laminae suggesting deposition via turbidity currents
(Pelikán, 1987, 2005; Csontos, 1988). Siliciclastic sandstone assigned to the Vaskapu Sandstone Formation (Pelikán, 2005) occurs in the southern part of the study area, northeast of the village of Bükkzsérc, above Triassic beds, at the basal part of the Jurassic succession (Fig. 3). Owing to the lack of any biostratigraphic data, the stratigraphic position of this formation is not known. However, in some places similar sandstone bodies occur within or above the Lökvölgy Formation (Pelikán, 2005). Consequently, it is probable that this sandstone has an interfingering connection with the Lökvölgy Formation (Pelikán, 2005) and does not belong to the overlying Mónosbél Group.

The calcareous and siliceous basin and redeposited slope facies have been defined as the Mónosbél Group (Pelikán, 2005). Within the group several lithofacies can be distinguished. These were defined as individual formations, but in many cases they show interfingering or transitional features and some of them may appear as redeposited clasts and blocks. The Oldalvölgy Formation is typically made up of an alternation of dark grey cherty limestone and black shale (silty claystone, sandstone) layers. Most of the limestone layers have mudstone or peloidal wackestone texture, but ooids 


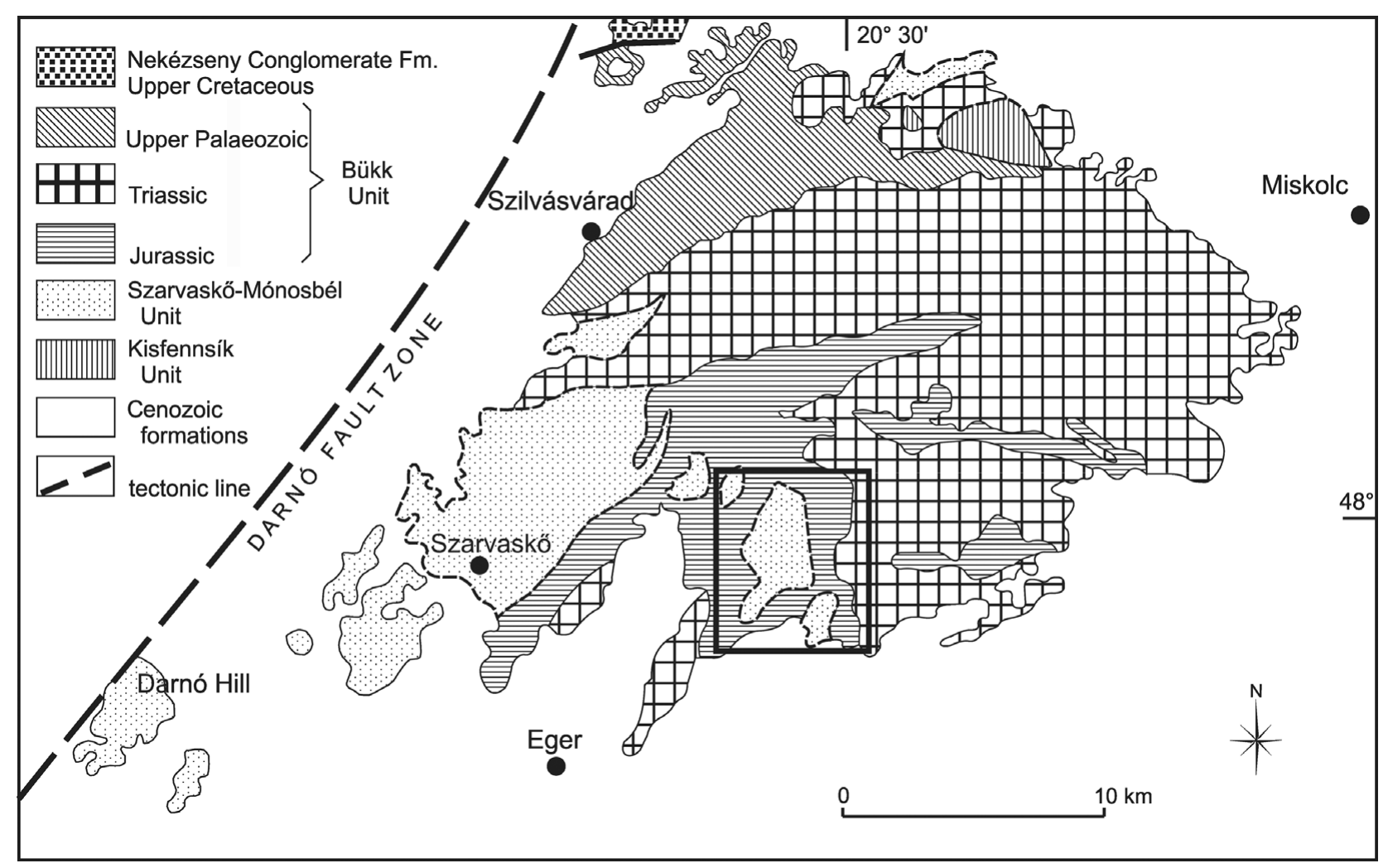

Figure 2. Simplified geologic map of the Bükk Mountains showing position of the study area.

or cortoids also occur in some beds. Radiolarian and/or sponge spicule wackestones are also typical textures of the formation. These gradually progress into radiolarian packstone, radiolarite and radiolarian chert beds, which can be assigned to the Csipkésteto" Radiolarite. The Oldalvölgy Limestone and Csipkéstetö Radiolarite formed coevally; accordingly, their lateral and vertical transition is a common occurrence.

Polymictic olistostrome beds typify the upper part of the series, which was classified as part of the Mónosbél Formation (Pelikán, 2005; not to be confused with the Mónosbél Group, of which it forms a part; see Fig. 4 of this paper). Along with clasts of siliciclastic rocks, various volcanites and metamorphic rocks, oolitic carbonates resembling the Bükkzsérc Limestone are also common clastic components of these olistostromes.

The Bükkzsérc Limestone consists mostly of oolitic grainstone, as well as peloidal grainstone with intercalations of peloidal-'filament' wackestone and radiolarian wackestone, and packstone representing toe-of-slope apron and basin facies. However, rock types of this formation usually appear in the form of smaller or larger redeposited blocks (olistoliths) in the upper part of the Mónosbél Group (Haas et al. 2006) (Fig. 4).

To the west of the studied area Jurassic basic magmatic rocks occur. They consist of basalt characterized by hyaloclastic lava flows and pillow lavas (Szarvaskö Basalt Formation), which were formed by submarine volcanic activity, and intrusive gabbro bodies (Tardos Gabbro Formation) (Fig. 3).
The Palaeozoic-Mesozoic formations of the Bükk Mountains were subjected to very low- and low-grade regional metamorphism (temperatures of $200-350{ }^{\circ} \mathrm{C}$, fluid pressures of 1.5-3 kbar; maximum $5 \mathrm{kbar}$, locally) (Árkai, 1983). The grade of metamorphism decreases from north to south from the epizone to the lower temperature part of the anchizone, as well as to the zone of medium-deep diagenesis (Árkai, 1983). Diagenetic to very low-grade metamorphic alteration characterizes the study area in the southwestern part of the Bükk Mountains. According to the latest studies performed on Jurassic formations of this area, the Kübler index and the chlorite 'crystallinity' data do not indicate any significant difference in the grade of alteration between the Lökvölgy Formation and the shale of the Mónosbél Group (Árkai \& Judik, pers. com.). Based on K-Ar age dating, regional metamorphism of the PalaeozoicMesozoic formations occurred in two stages, at 160 $120 \mathrm{Ma}$ and 100-95 Ma, respectively (Árkai, Balogh \& Dunkl, 1995).

\section{Key sections}

The area in the neighbourhood of the village of Bükkzsérc, in the southwestern part of the Bükk Mountains, is crucial for understanding the stratigraphy and lithology of the Jurassic sequences of this region. At the type locality of the Bükkzsérc Limestone, a number of outcrops of olistostrome beds of the Mónosbél Group are found; moreover, core sections (Bzs-5, -10, -11) are also available. Detailed sedimentological, petrographic and palaeontological 


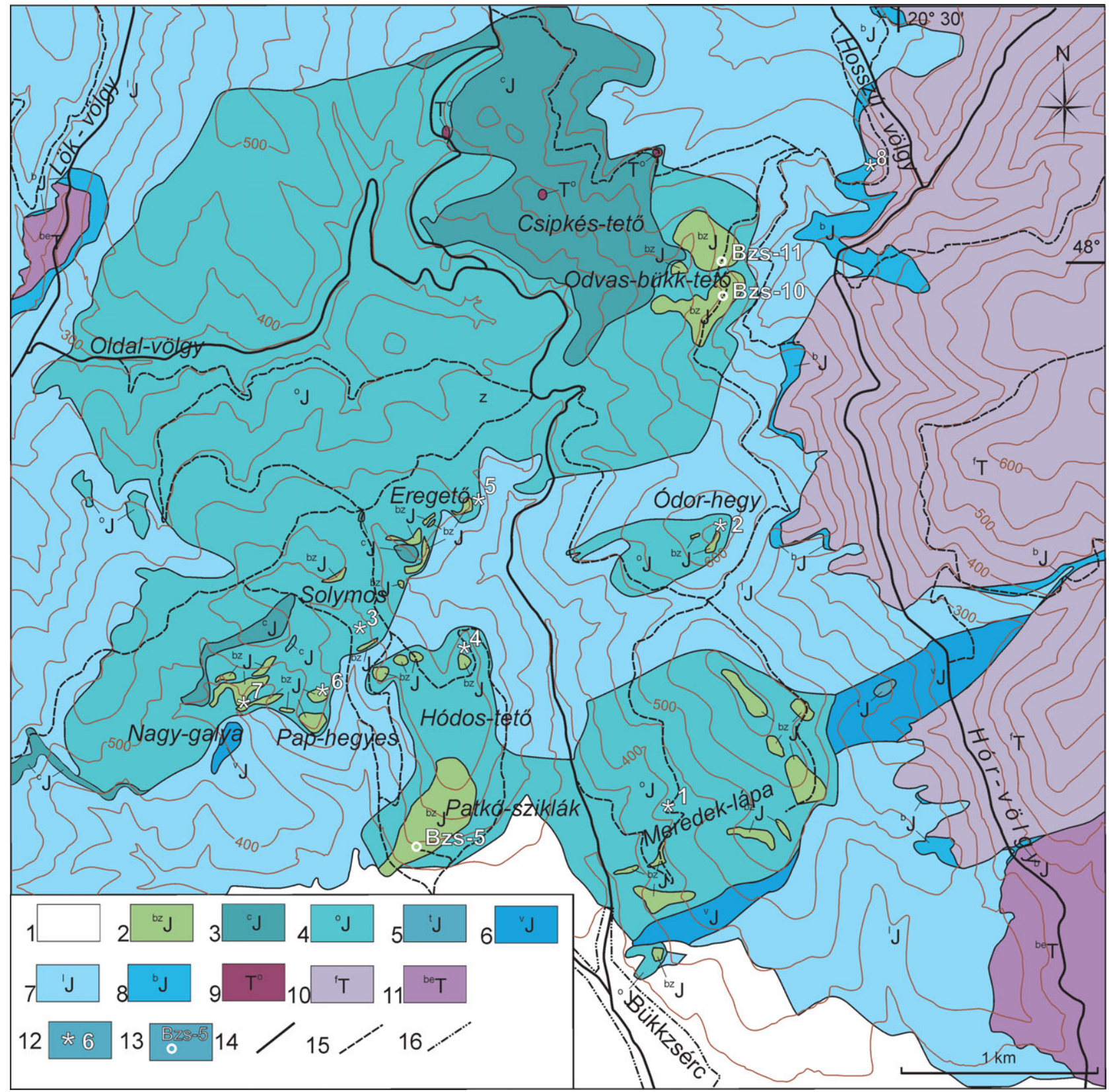

Figure 3. (Colour online) Geologic map of the study area showing location of the studied cores and outcrops. Legend: (1) Cenozoic formations; (2) Bükkzsérc Limestone Formation; (3) Csipkéstető Radiolarite Formation; (4) Oldalvölgy Limestone Formation; (5) Tardos Gabbro Formation; (6) Vaskapu Sandstone Formation; (7) Lökvölgy Formation; (8) Bányahegy Radiolarite Formation; (9) Olistoliths made up of Triassic pelagic carbonates and basalt; (10) Felsőtárkány Limestone Formation; (11) Berva Limestone Formation; (12) outcrops referred to in the paper; (13) studied boreholes; (14) asphalt road; (15) forest road; (16) settlement outline.

investigations were carried out on the cores and samples taken from a number of outcrops (Meredek-lápa, Ódor-hegy, Solymos, Hódos-tető, Eregető, Pap-hegyes, Nagy-galya) for timing and better understanding the very complex rock-forming processes. Locations of the investigated cores and outcrops are presented in Figure 3. The lithological characteristics of the clastic components of the olistostromes in the studied outcrops are summarized in Table 1.

\section{3.a. Core Bzs-11 and related outcrops}

Core Bzs-11 was cut on the eastern slope of Odvasbükk-tetö (Fig. 3). The lower part of the cored section
$(115.2-135.0 \mathrm{~m})$ can be assigned to the Lökvölgy Formation (Fig. 4). In the lowermost part of the core $(130.0-135.0 \mathrm{~m})$, dark grey sandstone and silty shale alternate. Graded bedding was recognized in the $131.7-132.7 \mathrm{~m}$ interval with mudstone rip-up clasts in the basal coarse-grained sandstone. It is followed by silicified silty shale containing various amounts of radiolarians $(121.6-130.0 \mathrm{~m})$. In two samples (129.7 and $125.2 \mathrm{~m})$, a few foraminifera (Labalina rawiensis, Labalina sp., Nodosaria sp. and Cylindrotrocholina excelsa) were observed in sandstone (Fig. 6). The next interval (115.0-121.6 m) is typified by an alternation of sandstone and shale. 


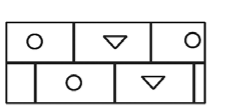

Mónosbél

olistostrome 3

Late Bathonian
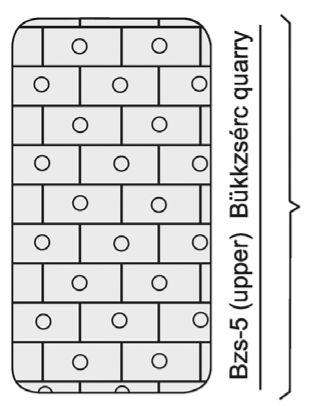

Late Bajocian

Bükkzsérc

Limestone

(olistolith)

Aalenian(?)

Early Bajocian

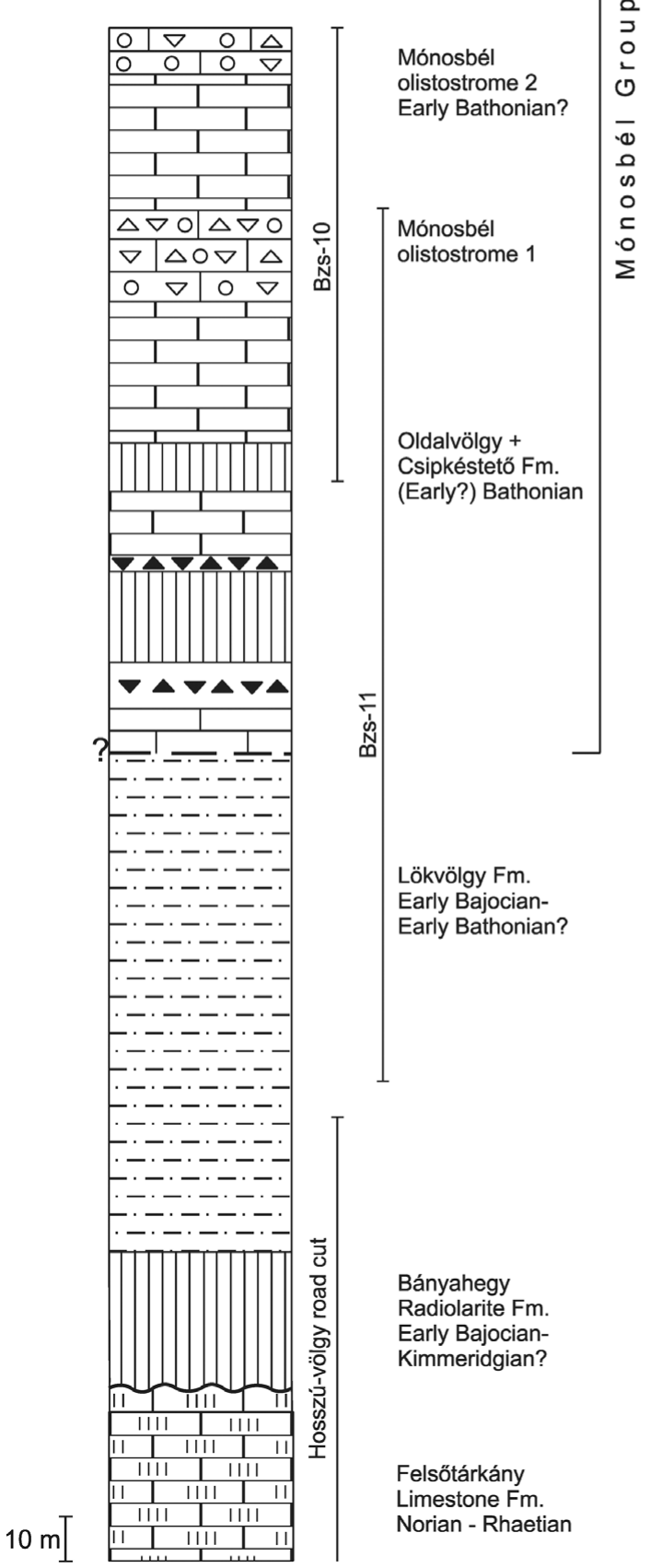

0
2
0
1
0
-1
0
0
0
5
0
$\Sigma$
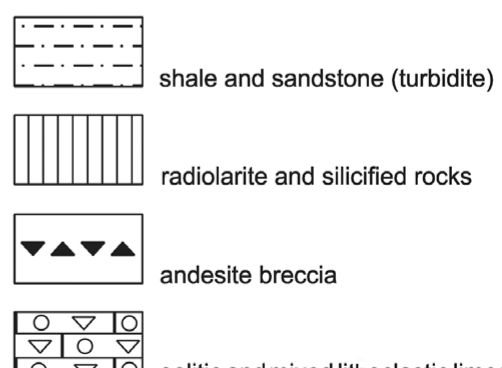

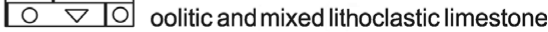
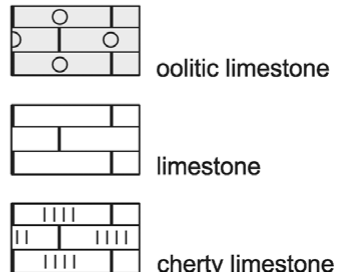

Figure 4. General lithostratigraphic succession of the study area with indication of age data based on biostratigraphic results of the present study. 
Table 1. Lithological types of clastic components of olistostromes of the core Bzs-11 and outcrops studied

\begin{tabular}{|c|c|c|c|c|c|c|c|c|c|c|c|c|c|c|c|c|c|c|c|c|c|c|c|c|}
\hline Samples & 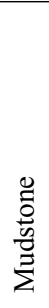 & $\begin{array}{l}\frac{3}{\pi} \\
\frac{\pi}{0} \\
0 \\
0 \\
0\end{array}$ & $\begin{array}{l}3 \\
0 \\
\frac{0}{3} \\
.0 \\
0 \\
0 \\
0 \\
0 \\
\tilde{0} \\
\text { के }\end{array}$ & 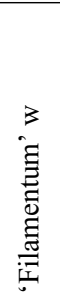 & 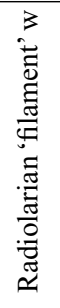 & 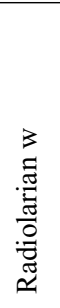 & $\begin{array}{l}\frac{3}{3} \\
\frac{\pi}{0} \\
\frac{0}{0} \\
2\end{array}$ & $\begin{array}{l}3 \\
: 0 \\
: 0 \\
0\end{array}$ & : & 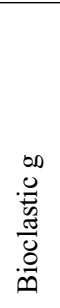 & $\begin{array}{l}\frac{00}{\pi} \\
\frac{\pi}{0} \\
\frac{0}{0} \\
2\end{array}$ & $\begin{array}{l}\stackrel{0}{\Xi} \\
\stackrel{0}{0} \\
\stackrel{0}{\circ}\end{array}$ & 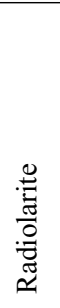 & 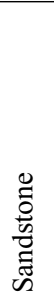 & 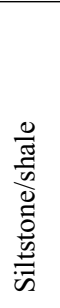 & 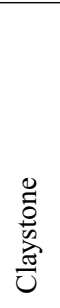 & $\begin{array}{l}\stackrel{0}{0} \\
\stackrel{\overrightarrow{0}}{\simeq}\end{array}$ & 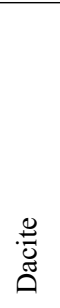 & $\begin{array}{l}\frac{0}{0} \\
\frac{0}{0} \\
\frac{0}{2}\end{array}$ & 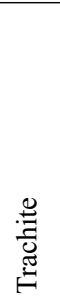 & $\begin{array}{l}\overrightarrow{\tilde{J}} \\
\tilde{\tilde{J}} \\
\tilde{D}\end{array}$ & 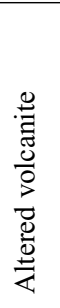 & 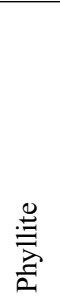 & 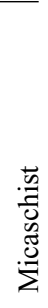 \\
\hline Bzs-11, 98.7-102.1 m & & & & & & & & & & & & & $\mathrm{x}$ & & $\mathrm{x}$ & & & & o & & & & & \\
\hline Bzs-11, 58.5-59.2 m & & & & & & & & & & & & & & & & & & & o & o & o & & & \\
\hline Bzs-11, 3.5-6.6 m & & & & & & & & & & & & & & & & & o & $\mathrm{x}$ & $\mathrm{x}$ & $\mathrm{x}$ & & & & \\
\hline Bzs-11,0.0-3.5 m & $\mathrm{x}$ & & & $\mathrm{x}$ & & & & & & & & & & $\mathrm{x}$ & $\mathrm{x}$ & & & & & & & & & $\mathrm{x}$ \\
\hline Meredek-lápa & $\mathrm{x}$ & $\mathrm{x}$ & $\mathrm{x}$ & & $\mathrm{x}$ & & & $\mathrm{x}$ & & & $\mathrm{x}$ & & $\mathrm{x}$ & $\mathrm{x}$ & $\mathrm{x}$ & $\mathrm{x}$ & & & & & & & $\mathrm{x}$ & $\mathrm{x}$ \\
\hline Ódor-hegy & $\mathrm{x}$ & & & & & $\mathrm{x}$ & & & & $\mathrm{x}$ & & & & $\mathrm{x}$ & & & & & & & & $\mathrm{x}$ & & \\
\hline Solymos & $\mathrm{x}$ & $\mathrm{x}$ & $\mathrm{x}$ & $\mathrm{x}$ & & $\mathrm{x}$ & & & & & & & & $\mathrm{x}$ & & & $\mathrm{x}$ & & & & & & & \\
\hline Hódos-tető & $\mathrm{x}$ & $\mathrm{x}$ & $\mathrm{x}$ & $\mathrm{x}$ & & & & & $\mathrm{x}$ & $\mathrm{x}$ & $\mathrm{x}$ & $\mathrm{x}$ & & $\mathrm{x}$ & $\mathrm{x}$ & & $\mathrm{x}$ & & & & $\mathrm{x}$ & & $\mathrm{x}$ & \\
\hline Erege & $\mathrm{x}$ & & & $\mathrm{x}$ & & & & & & & & $\mathrm{x}$ & $\mathrm{x}$ & $\mathrm{x}$ & $\mathrm{x}$ & $\mathrm{x}$ & & & & & & & & $\mathrm{x}$ \\
\hline Pap-h & $\mathrm{x}$ & & $\mathrm{x}$ & & & & $\mathrm{x}$ & & $\mathrm{x}$ & & & $\mathrm{x}$ & & $\mathrm{x}$ & & & & & & & $\mathrm{x}$ & & & \\
\hline Nagy-galya & $\mathrm{x}$ & & $\mathrm{x}$ & & $\mathrm{x}$ & $\mathrm{x}$ & & & & & $\mathrm{x}$ & $\mathrm{x}$ & & $\mathrm{x}$ & $\mathrm{x}$ & & & & & & $\mathrm{x}$ & & $\mathrm{x}$ & \\
\hline
\end{tabular}

Abbreviations: $\mathrm{w}$ - wackestone; $\mathrm{p}$ - packstone, $\mathrm{g}$ - grainstone; $\mathrm{x}$ - occur, $\mathrm{o}$ - abundant.

The predominantly shaly interval is overlain by a limestone unit $(22.8-115.0 \mathrm{~m})$ that is defined by radiolarian and sponge spicule wackestone microfacies (Fig. 5). The limestone is commonly silicified, partially or pervasively. Radiolarite interbeds also occur. Thus, this unit can be assigned to the Oldalvölgy-Csipkéstetö Formation.

In a few samples taken from this interval, a relatively poor radiolarian fauna was recorded (Pelikán \& Dosztály, 2000; Haas et al. 2006). Peloidal packstone and grainstone containing smaller or larger amounts of recrystallized miliolid foraminifera (Labalina costata, L. occulta, L. rawiensis, Ophthalmidium caucasicum, $O$. aff. concentricum, Cornuspira infraoolithica), and a few agglutinated forms (Trochammina spp., Valvulina spp., Textularia spp., Mesoendothyra croatica) were encountered (Fig. 6). The richest foraminifer assemblage was found at $33.3-32.2 \mathrm{~m}$ (Fig. 5). The Textulariidae and especially the Nodosariidae are usually rare throughout the core, except at $77.5 \mathrm{~m}$ where the agglutinated TVT (Trochammina-ValvulinaTextularia) group is relatively frequent.

There is a $4 \mathrm{~m}$ thick red and green volcaniclastic interval (98.7-102.1 m) in the lower part of the carbonate-dominated succession that is made up predominantly of strongly altered and silicified fragments of basaltic and trachitic andesite (Fig. 7h). Moreover, a few radiolarite, silicified shale and carbonate clasts occur. Thinner volcaniclastic horizons were found at 58.5-59.2 $\mathrm{m}$ and at 40.2-41.4 m. Here trachitic, microholocrystalline andesite and chloritic basalt clasts were observed in a radiolarian wackestone matrix.

The uppermost part of the limestone-dominated interval described above is shaly and typified by radiolarian and sponge spicule wackestone microfacies with peloidal grainstone interlayers (Fig. 8e). This is overlain by polymictic olistostromes $(0.0-22.8 \mathrm{~m})$. The lowermost olistostrome ('micro-olistostrome') beds are made up of coarse calcarenite and fine calcirudite
(Fig. 8c). The typical texture is lithoclastic, bioclastic, oolitic grainstone, packstone or wackestone (Fig. 8f, g). The matrix is commonly argillaceous. Among the lithoclasts, the carbonates (sponge spicule and radiolarian wackestone, peloidal grainstone, micritic mudstone, 'filamentum' wackestone, dolomicrosparite and dolosparite) are predominant but shale, chert and altered volcanic rocks also occur. In the sample taken from $20.2 \mathrm{~m}$ Labalina $\mathrm{cf}$. rawiensis, indicating a Middle Jurassic age, was encountered in the matrix, whereas a Late Triassic-Early Jurassic foraminifera fauna (Paralingulina tenera, P. cf. testudinaria, Nodosaria spp. and Pseudonodosaria sp.) was found in a limestone clast. Coarse arenite-sized crinoid fragments are common. Millimetre-sized fragments of Rivularia-type calcimicrobe structures were also observed.

The lithoclasts vary increasingly upsection. Along with various carbonates, silty claystone, quartz sandstone and altered volcaniclasts are the most common components. A coarse-grained olistostrome containing mostly limestone and some sandstone clasts was penetrated between 16.0 and $18.6 \mathrm{~m}$.

In the next interval $(6.6-16.0 \mathrm{~m})$ oolitic packstone and grainstone prevail, but coarse arenite to fine rudite-sized polymictic lithoclasts also commonly occur (Fig. $7 \mathrm{~g}$ ). In the $15.5 \mathrm{~m}$ sample, the Triassic Triadodiscus cf. eomesozoicus was recognized in carbonate lithoclasts (Fig. 6). This interval is followed by coarse-grained volcaniclastic beds $(3.5-6.6 \mathrm{~m})$. In these beds, the volcanic material is very variable. Clasts of rhyolite, dacite, trachyte and andesite were recognized (Figs 7b-f, 8a, b).

Above the volcaniclastic olistostromes, in the topmost part of the core $(0.0-3.5 \mathrm{~m})$, peloidal grainstone with clasts of carbonates (micritic mudstone, filamentum microsparite, and sparite) quartz sandstone (Fig. 7a), shale and altered volcanites and oolitic 


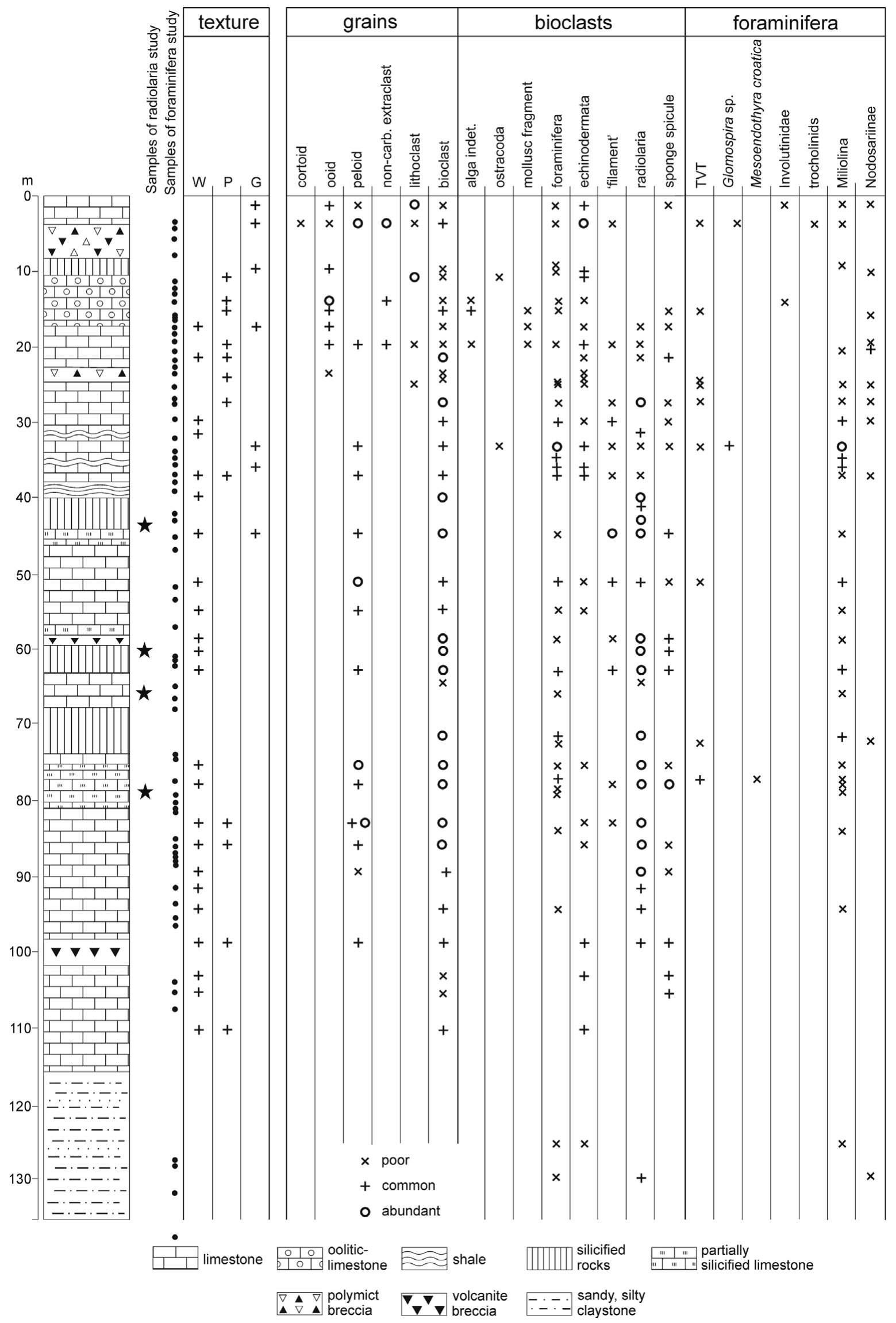

Figure 5. Lithology, microfacies characteristics and distribution of foraminifera in core Bzs-11. 

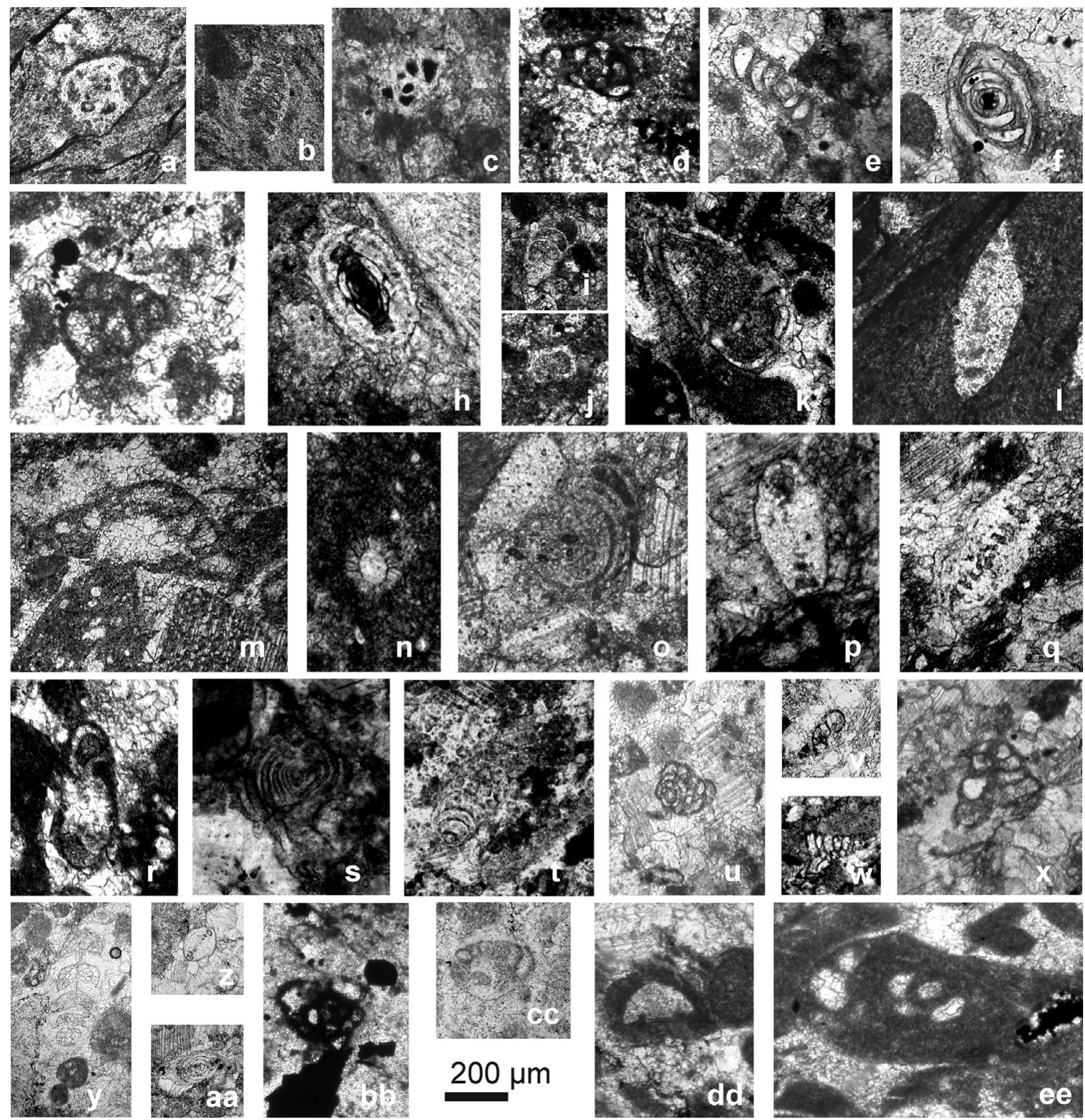

Figure 6. Characteristic Triassic (1, o-r) and Jurassic $(\mathrm{a}-\mathrm{k}, \mathrm{m})$ foraminifera and incertae sedis of cores Bzs-11 and Bzs-10, and Odvasbükk-tető outcrop: (a) Labalina rawiensis (Pazdrowa, 1959), Bzs-11 (125.2 m), (b) Cylindrotrocholina excelsa (Ruggieri \& Giunta, 1965), Bzs-11 (125.2 m), (c) Labalina costata (Antonova, 1958b), Bzs-11 (72.3 m), (d) Labalina occulta (Antonova, 1958a), Bzs-11 (32.2 m), (e) Ophthalmidium caucasicum (Antonova, 1958a), Bzs-11 (32.2 m), (f) O. aff. concentricum (Terquem \& Berthelin, 1875) Bzs-11 (33.3 m), (g) Textularia sp., Bzs-11 (33.1 m), (h) Labalina cf. rawiensis (Pazdrowa, 1959), Bzs-11 (20.2 m), (i, j) Paralingulina tenera (Bornemann, 1854), Bzs-11 (20.2 m), (k) Pseudonodosaria sp., Bzs-11 (20.2 m), (1) Triadodiscus cf. eomesozoicus (Oberhauser, 1957), Bzs-11 (15.5 m), (m) Trocholina palastiniensis Henson, 1948, Bzs-11 (3.5-3.0 m), (n) Parastomiosphaera sp., Bzs-11 (3.53.0 m), (o) Triasina cf. oberhauseri Koehn-Zaninetti \& Brönnimann, 1968, Bzs-11 (2.7 m), (p, q) Angulodiscus sp., Bzs-11 (2.7 m), (r) Auloconus permodiscoides (Oberhauser, 1964), Bzs-11 (2.7 m), (s) Ophthalmidium?, Bzs-11 (2.7 m), (t) Paralingulina testudinaria (Franke, 1936), Bzs-10 (62.0 m), (u) Glomospira sp., Bzs-10 (61.3 m), (v) Trochammina sp., Bzs-10 (46.4 m), (w) Verneuilinoides sp., Bzs-10 (62.0 m), (x) Valvulina sp., Bzs-10 (62.0 m), (y) Nodosaria sp., Bzs-10 (19.2 m), (z) O. aff. concentricum (Terquem \& Berthelin, 1875), recrystallized, Bzs-10 (61.3 m), (aa) Labalina cf. rawiensis (Pazdrowa, 1959), recrystallized, Bzs-10 (61.3 m), (bb) Labalina costata (Antonova, 1958b), Bzs-10 (87.0 m), (cc) Protopeneroplis striata Weynschenk, 1950, Odvas-bükk-tetö, (dd) Trocholina sp., Odvas-bükk-tetö, (ee) Nautiloculina oolithica Mohler, 1938, Odvas-bükk-tető.

grainstone with carbonate lithoclasts were exposed. In sample 3.5-3.0 m Jurassic microfauna (e.g. Trocholina palastiniensis, Labalina sp., Parastomiosphaera sp.), and in sample $2.7 \mathrm{~m}$ Norian foraminifera
(Triasina cf. oberhauseri, Auloconus permodiscoides, Angulodiscus sp., Ophthalmidium? sp.) of carbonate platform origin were recognized in lithoclasts (Fig. 6). 

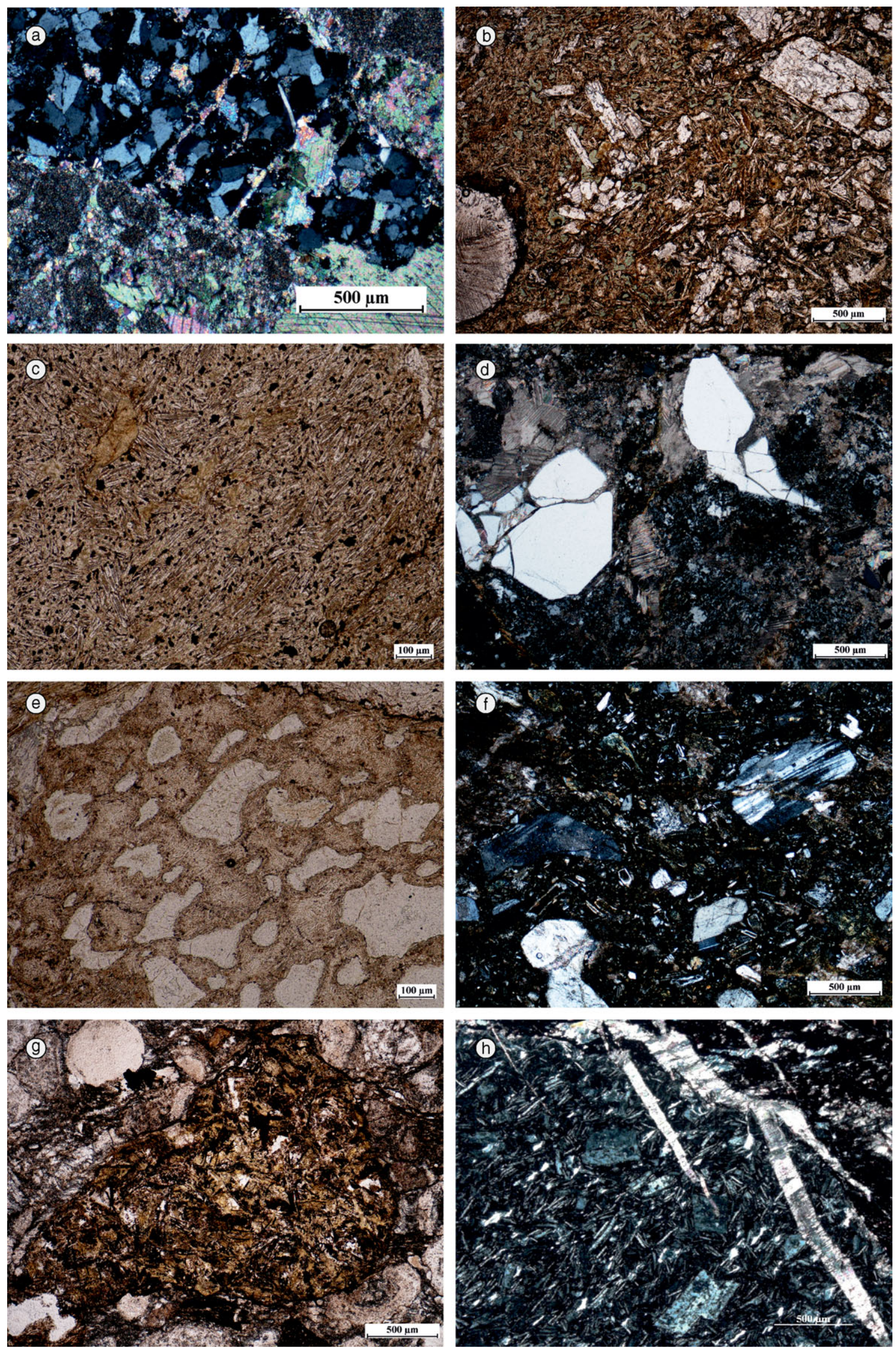

Figure 7. Typical clastic components of olistostromes in core Bzs-11: (a) elongated, rounded sandstone clast $(+\mathrm{N}), 3.0-3.5 \mathrm{~m}$. (b) Intersertal porphyric basalt clast with calcite filled amygdale and plagioclase phenocrysts $(1 \mathrm{~N}), 4.3 \mathrm{~m}$. (c) Intersertal-trachitic basalt clast $(1 \mathrm{~N}), 4.3 \mathrm{~m}$. (d) Broken quartz phenocrysts in recrystallized matrix of a rhyolite clast $(+\mathrm{N}), 4.3 \mathrm{~m}$. (e) Amygdalodial basalt clast $(1 \mathrm{~N}), 4.3 \mathrm{~m}$. (f) Porphyric andesite clast with plagioclase phenocrysts $(+\mathrm{N}), 5.2 \mathrm{~m}$. $(\mathrm{g})$ Strongly altered intersertal dolerite clast $(1 \mathrm{~N})$, 14-14.2 m. (h) Porphyritic-trachytic andesite clast with plagioclase phenocrysts and carbonatic vein $(+\mathrm{N}), 100.0 \mathrm{~m}$. 

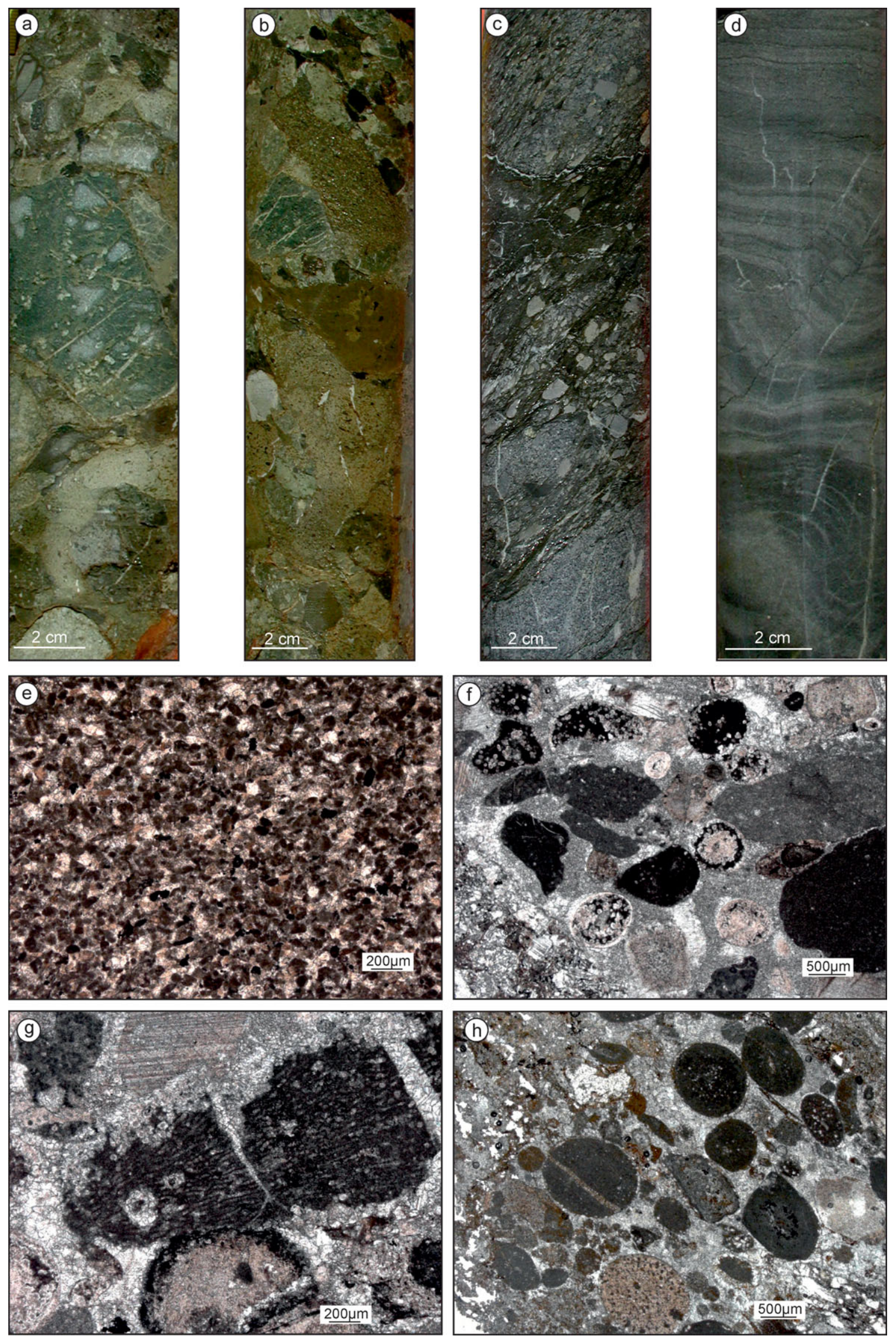

Figure 8. Typical lithological features and microfacies of the Mónosbél Group in cores Bzs-10 and Bzs-11: (a) grain-supported polymict breccia-conglomerate (olistostrome), Bzs-11 $(4.3-4.5 \mathrm{~m})$. (b) Grain-supported polymict breccia-conglomerate containing a large amount of volcaniclasts, Bzs-11 (4.5-4.8 m). (c) Mud-supported oligomict breccia (debrite), Bzs-11 (18.1-18.5 m). (d) Slump structures in pelagic limestone, Bzs-11 (90.9-90.8 m). (e) Fine-grained peloidal grainstone, Bzs-11 (34.8 m). (f) Medium-grained lithoclastic grainstone with ooid moulds, Bzs-11 $(22.8 \mathrm{~m}) .(\mathrm{g})$ Rivularia fragment and echinoderm detritus, Bzs-11 (22.8 m). (h) Peloidal grainstone. The globular peloids are probably micritized ooids or oncoids, Bzs-10 $(19.0 \mathrm{~m})$ 
The characteristic volcaniclastic interval is also exposed at the surface in a road-cut close to the site of the borehole. In the surface exposure, there are debrite (olistostrome) beds, containing various amounts of clasts, mostly of volcanic rocks. In one of these beds unsorted, unrounded to well-rounded clasts, $1-15 \mathrm{~cm}$ in size occur in a shale matrix. The clasts are mostly of rhyolite, typically with glauconitized rhombic pyroxene, plagioclase and a few resorbed quartz grains. A cumuloporphyric andesite containing glauconitized rhombic pyroxene, and another andesite clast were also found.

This bed is overlain by a limestone bed that also contains sandstone (partly metasandstone) clasts (Fig. 9h) and volcaniclasts, of a maximum size of $1 \mathrm{~cm}$. The volcaniclasts are weathered and their minerals are strongly altered. However, based on the textures of the rocks, it is plausible that predominantly basic rock types occur, showing an appearance akin to that of basite of ophiolite complexes. The following rock types were recognized: sphaerolithic volcanite, intergranular dolerite, intersertal-variolitic amygdaloidal basalt, intergranular metabasalt and amygdaloidal volcanite (Fig. 9b-d, f, g). Rhyolite with resorbed quartz and volcanites with porphyritic plagioclase were also found, subordinately (Fig. 9e).

$\mathrm{U}-\mathrm{Pb}$ age determination was recently carried out on zircon grains separated from acidic volcanite clasts. From this locality, only one data pair was concordant, yielding an age of $222 \pm 18 \mathrm{Ma}$. However, also taking into account the concordant age data measured on similar volcanite clasts found in the olistostromes of the neighbouring Rudabánya Hills, $227.3 \pm 4.4 \mathrm{Ma}$ is the probable age of volcanism (Late Ladinian-Early Carnian) (Haas et al. 2011). This corresponds to the age of the late stage of the Ladinian-Carnian volcanism in the Bükk Mountains (Pelikán, 2005).

\section{3.b. Core Bzs-10}

Core Bzs-10 (Fig. 10) was cut about $300 \mathrm{~m}$ south of core Bzs-11 and exposed a sequence corresponding to the upper part of the section encountered by the latter.

The lower part of the core $(65.5-87.0 \mathrm{~m})$ is made up mostly of radiolarite, which can be correlated with the predominantly radiolaritic interval in core Bzs-11 (38-73 m). Above it, peloidal-bioclastic packstone and grainstone, as well as oolitic grainstone, were found $(51.0-61.3 \mathrm{~m})$. In the oolitic grainstone beds (59.1$62.0 \mathrm{~m}$ ) carbonate lithoclasts (radiolarian wackestone and mudstone) occur. In some lithoclasts Early Jurassic foraminifera associations (Paralingulina tenera, $P$. testudinaria, Nodosaria spp., Pseudonodosaria sp. and Glomospira sp.) were encountered; a very similar horizon was found at 35.8-32.2 $\mathrm{m}$ in core Bzs-11.

The next interval $(11.7-51.0 \mathrm{~m})$ is typified by an abundance of sponge spicules. The foraminifera fauna is very poor; a few specimens of miliolinids (e.g. Labalina rawiensis, Ophthalmidium aff. concent- ricum), Glomospira sp., Textularia sp., Nodosaria spp. and Lenticulina sp. could be identified.

An olistostrome interbed (lithoclastic, oolitic, bioclastic grainstone) was encountered between 19.0$21.0 \mathrm{~m}$ (Fig. 8h). There are well-preserved ooid grains present; peloids are common and intraclasts also occur. Crinoid ossicles are abundant. The following lithoclast types were found: coarse sandstone, metasandstone, metasiltstone, quartzite with mica, holocrystalline microspherulitic rhyolite, strongly limonitized variolithic basalt and strongly altered microcrystalline volcanites with porphyric feldspars. Another polymictic breccia bed (olistostrome) was found between 11.4-12.3 m.

Oolitic grainstone and oolitic wackestone with millimetre-sized lithoclasts characterize the uppermost part of the core section $(0-11.7 \mathrm{~m})$. Carbonate lithoclasts (mudstone, bioclastic wackestone, peloidal microsparite) occur; moreover, sandstone, siltstone and strongly altered volcanite clasts (intergranular dolerite, intersertal basalt, chloritic, finely crystalline basic volcanite, andesite and microcrystalline rhyolite) were recognized.

Above the polymictic olistostrome horizon, which was penetrated by both corings, the lithofacies of the Oldalvölgy Formation continues upsection, and blocks (probably olistoliths) of the Bükkzsérc Limestone were mapped on the top of Odvas-bükk-tetö (Fig. 3). The Bükkzsérc Limestone is characterized by an oolitic, peloidal, bioclastic grainstone texture, containing crinoids, foraminifera and micritic lithoclasts. Textulariids (Textularia sp., Valvulina sp. and Nautiloculina oolithica), Trocholina sp., Protopeneroplis striata, miliolinids (Labalina spp., Ophthalmidium spp.), large lenticulinids and Pseudonodosaria sp. were found in the samples.

\section{3.c. Bükkzsérc Quarry, core Bzs-5 and Patkó-sziklák (Patkó cliffs)}

The largest occurrence of the Bükkzsérc Limestone is located northwest of the village of Bükkzsérc on the southern slope of the Hódos-teto locality. Here the rocks are exposed in an abandoned quarry (Bükkzsérc Quarry) and several outcrops (Patkó cliffs). Core Bzs-5 (Fig. 11) was cut in the yard of the quarry; accordingly, the succession exposed in the quarry can be considered as the continuation of the cored section, and this assumption is also supported by the foraminifera fauna.

In the lower part of core Bzs-5 (69.3-197.6 m) dark grey to black shale, i.e. an alternation of sandstone and clayey siltstone layers, was exposed. This interval can be assigned to the Lökvölgy Formation.

It is followed by polymictic breccia beds (olistostrome) and dark grey shale. The lower part of the breccia interval (66.7-69.3 m) contains predominantly quartzite components, but volcanites and carbonates also occur in a small amounts. The higher breccia beds $(64.4-66.7 \mathrm{~m})$ are made up of unrounded radiolarite fragments. They are overlain by an interval 

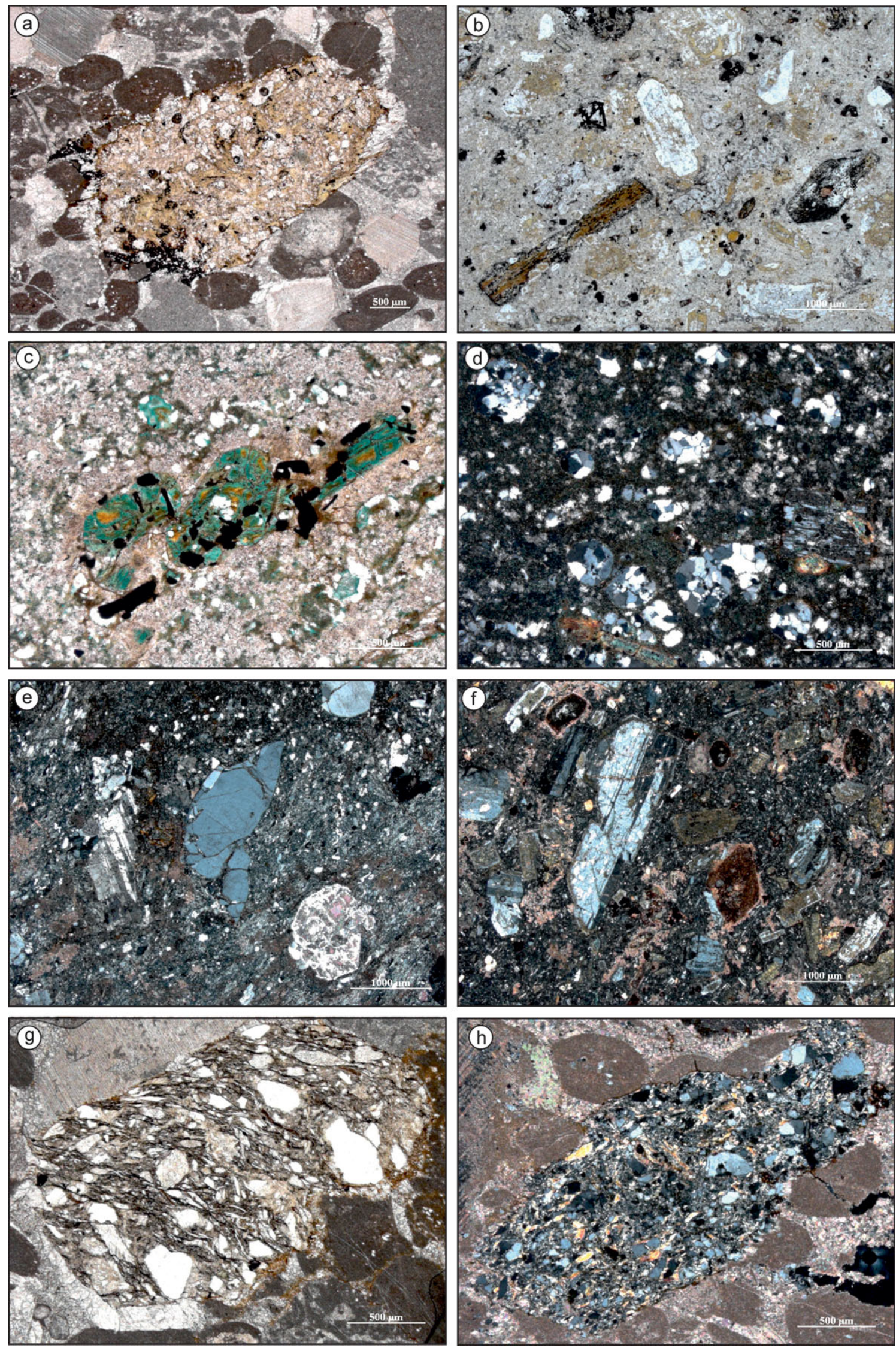

Figure 9. Typical clastic components of olistostromes from outcrop samples, Odvas-bükk-tetö. (a) Strongly altered intersertal dolerite clast (1N), sample 19. (b) Biotite-amphibole andesite clast (1N), sample 15. (c) Glauconitized orthorhombic pyroxene-opaque mineralapatite cumulate in dacite clast $(1 \mathrm{~N})$, sample 16b. (d) Silicified dacite clast with plagioclase and pyroxene phenocrysts $(1 \mathrm{~N})$, sample 16b. (e) Rhyolitic-dacitic clast with quartz and plagioclase phenocrysts $(+N)$, sample 6. (f) Amphibole andesite clast $(+N)$, sample 16. (g) Amphibole andesite clast $(+\mathrm{N})$, sample 16. (h) Metasandstone clast containing mainly quartz and muscovite $(+\mathrm{N})$, sample 19. 


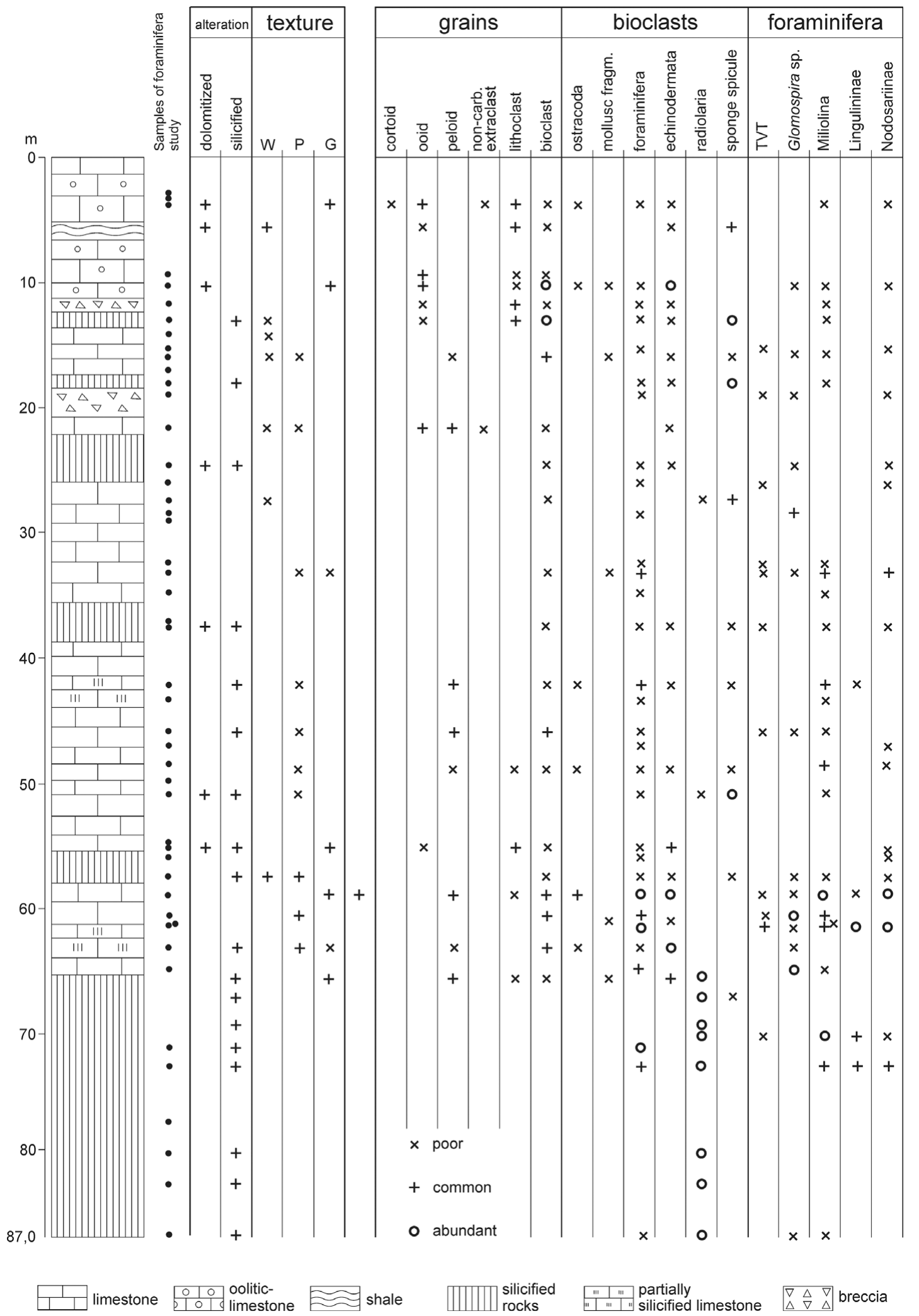

Figure 10. Lithology, microfacies characteristics and distribution of foraminifera in core Bzs-10.

(61.4-64.4 m) typified by an alternation of fine sandstone and claystone. No core was recovered from the interval between $55.2-61.6 \mathrm{~m}$ because a karstic cavern was penetrated. Dark grey limestone was found between $54.7-55.2 \mathrm{~m}$. That is overlain by dark shale with limestone breccia and limestone with claystone breccia grains $(52.1-54.7 \mathrm{~m})$. Oolitic limestone with thin black shale interlayers was exposed upsection (51.6-52.1 m).

The contact between the breccia-shale interval and the Bükkzsérc Limestone $(0.0-51.3 \mathrm{~m})$ is either tectonic or a matrix/olistolith boundary, or both (the 


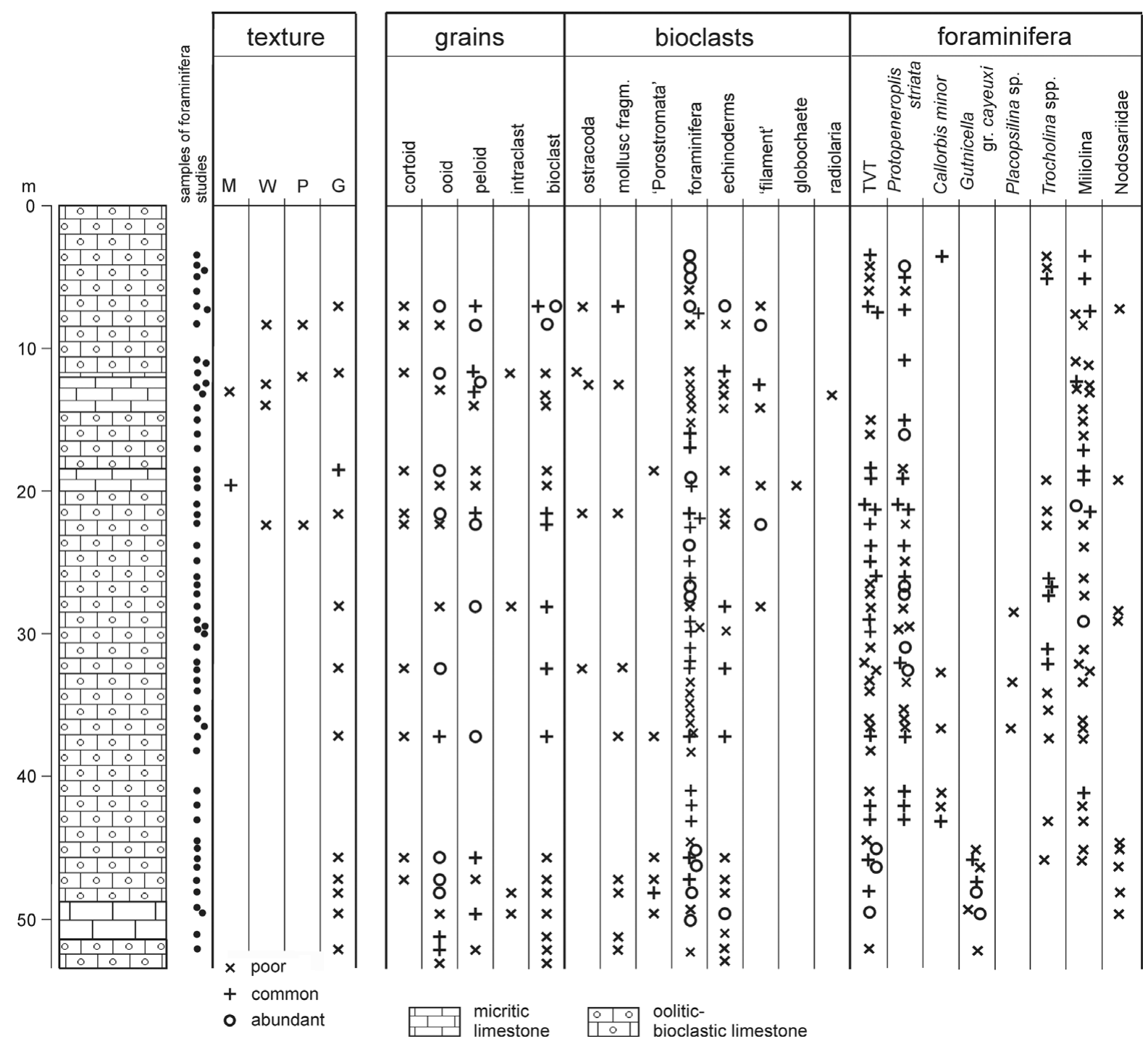

Figure 11. Lithology, microfacies characteristics and distribution of foraminifera in core Bzs-5.

recovery was rather poor near the contact). This discontinuity is also supported by biostratigraphic data (see Section 4). In the lower part of the Bükkzsérc Limestone the medium- to coarse-grained calcarenites of oolitic grainstone and oolitic-lithoclastic grainstone texture are the most typical (Fig. 12). Among the bioclasts, fragments of crinoids and molluscs are the most common, but detritus of Rivularia-type calcimicrobes are also abundant.

In the lower most part of the Bükkzsérc Limestone $(51.6-45.0 \mathrm{~m})$ the foraminifera fauna is characterized by the dominance of the agglutinated forms (TVT group), Mesoendothyra croatica and Gutnicella gr. cayeuxi (G. cayeuxi, G. brizonorum and G. minoricensis), indicating redeposition from the outer platform (sand shoal) environment. Mesoendothyra preferred the inner platform environment; it can be found in most of the section (up to sample 13 in the quarry), but only in small quantities. At $47.3 \mathrm{~m}$, large Paravalvulininae (Riyadella spp. and Redmondoides lugeoni) occur, and at $45.7 \mathrm{~m}$ trocholinas (Trocholina conica and T. palastiniensis) and miliolinids (Labalina spp., Ophthalmidium spp.) occur (Figs 11, 13). These latter groups, together with the TVT forms, are the most frequent in the upper part of the section (Figs 11, $13,14)$.

At $43.0 \mathrm{~m}$, Protopeneroplis striata appears in large numbers and this species occurs in almost every sample upsection (in core Bzs-5 and also in the quarry). At the same level, Callorbis minor also appears and occurs in the studied samples up to sample 13 in the quarry. Higher up (37, 32.4 and $27.9 \mathrm{~m}$ ) some specimens of an attached form belonging to the genus Placopsilina were recognized.

In the upper part of the cored section, the oolitic grainstone texture is still common but the grain size decreases (Fig. 12). Peloidal-'filament' wackestonepackstone and 'filament' mudstone interbeds also appear (Fig. 12). In the oolitic beds, clasts of deeperwater carbonates (peloidal-'filament' wackestonepackstone) and silicified radiolarian wackestone commonly occur. In some beds, along with carbonate lithoclasts, a few sand-sized shale and phyllite clasts and strongly altered volcaniclasts were also encountered 

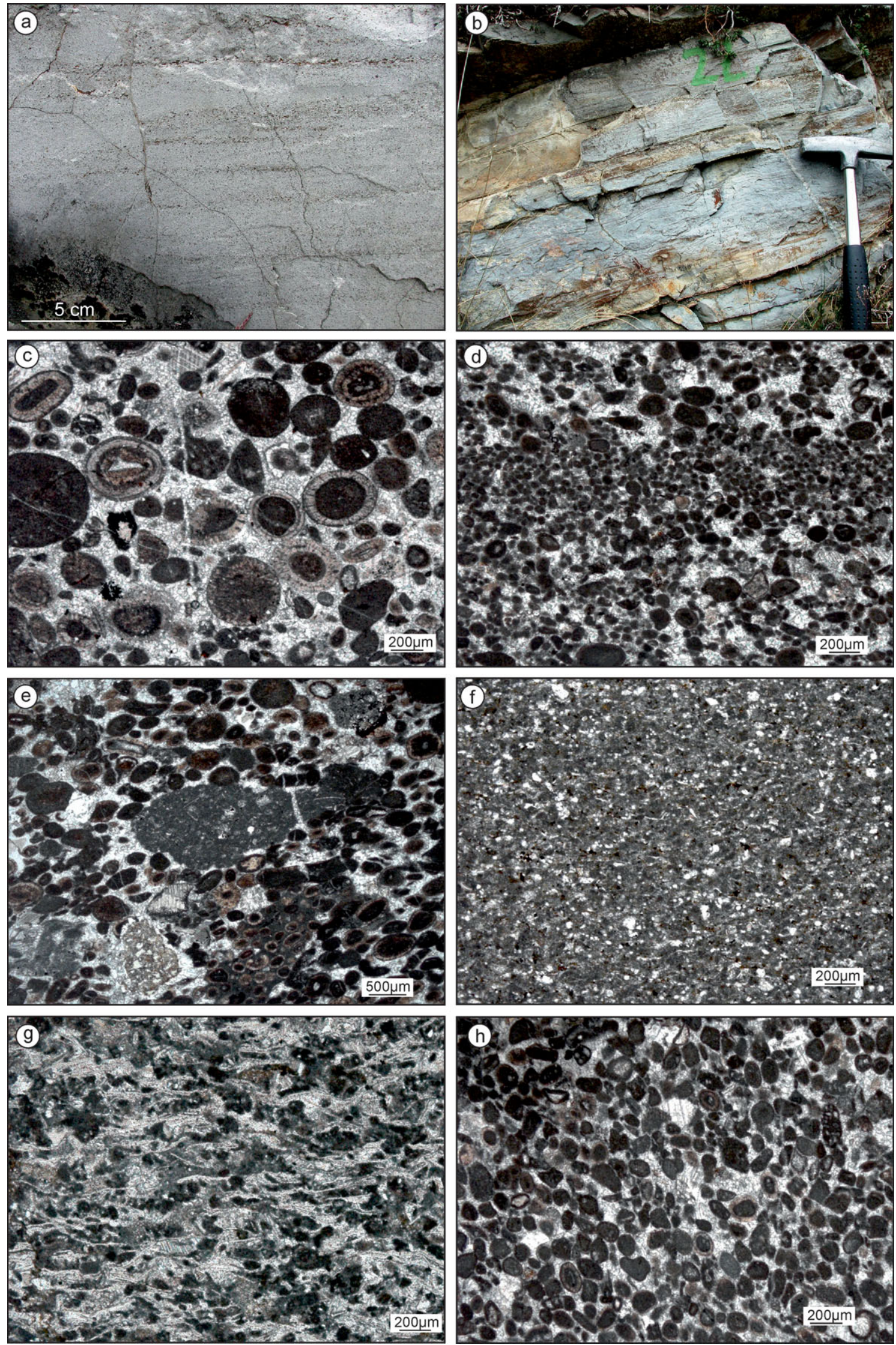

Figure 12. Lithological features and typical microfacies of the Bükkzsérc Limestone: (a) graded oolitic carbonate turbidites in the lower part of the Bükkzsérc Quarry (Bed 10). (b) Thin-bedded cherty limestone bed with sinusoid parallel lamination in the middle part and horizontal parallel lamination in the upper part of the bed, Bükkzsérc Quarry, upper part (Bed 22). (c) Oolitic grainstone; mediumgrained calcarenite. Some of the ooid grains were affected by micritization and then bioerosion; the others are only slightly altered. Bzs-5 (49.5 m). (d) Peloidal grainstone made up of alternation of graded laminae (distal turbidite). The peloids are mostly micritized ooids. Bzs-5 (45.0 m). (e) Oolitic, lithoclastic grainstone with oolitic packstone intraclast; radiolarian-'filament' wackestone lithoclast; sandy shale extraclast. (f) Peloidal wackestone with tiny 'filament' fragments. Bzs-5 (14.0 m). (g) Peloidal-'filament' packstone. Bzs-5 $(8.4 \mathrm{~m})$. (h) Peloidal, oolitic grainstone; fine-grained calcarenite. Bükkzsérc Quarry (Bed 14). 


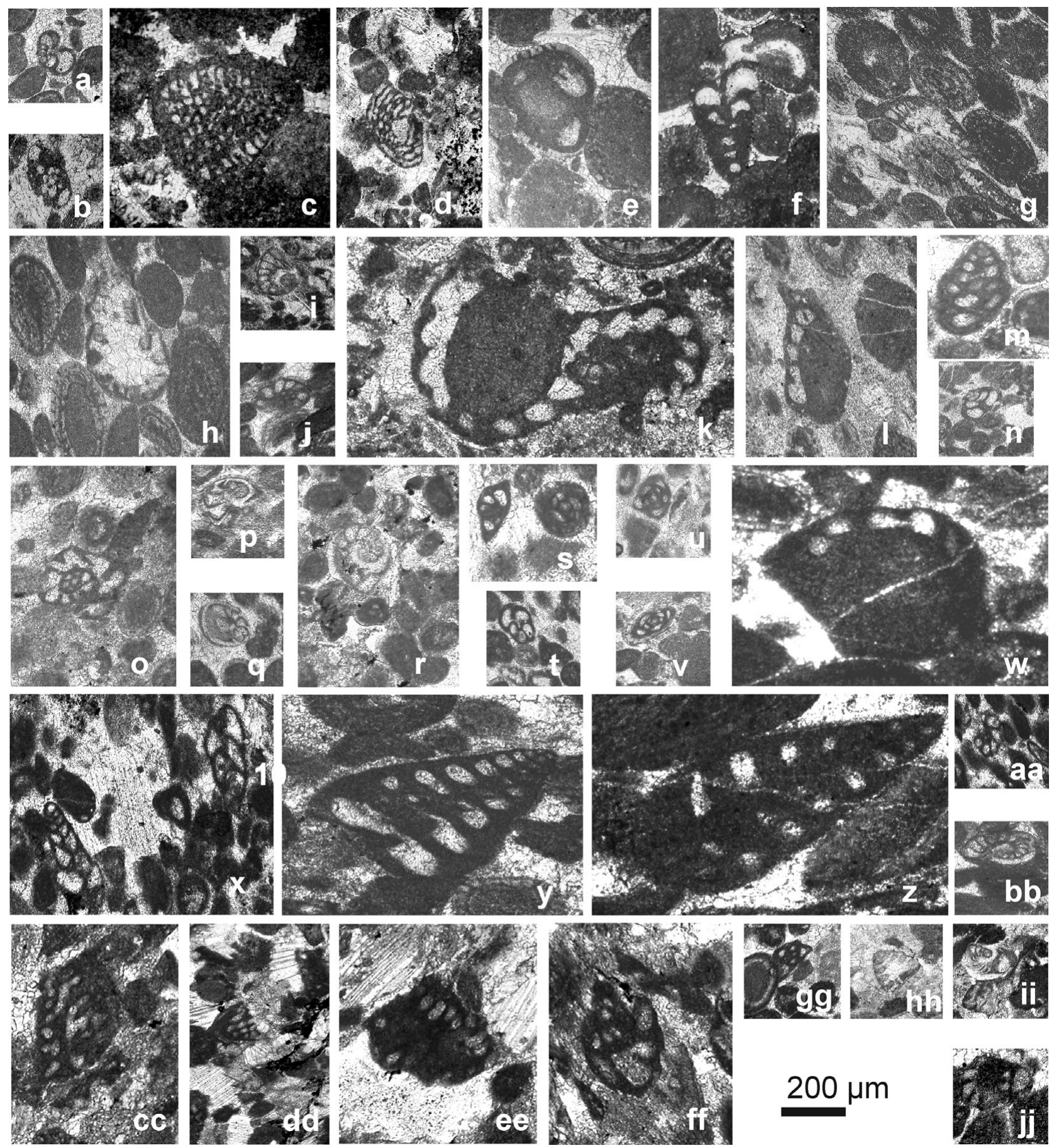

Figure 13. Characteristic foraminifera of the core Bzs-5, Bükkzsérc Quarry, Hódos-tető, Eregető and Pap-hegyes outcrops: (a) Trochammina sp., Bzs-5 (49.5 m); (b) Mesoendothyra croatica Gušić, 1969, Bzs-5 (42.0 m); (c) Gutnicella minoricensis (Bourrouilh \& Moullade, 1963), Bzs-5 (48.0 m); (d) Gutnicella cayeuxi (Lucas, 1939), Bzs-5 (46.2 m); (e) Redmondoides lugeoni (Septfontaine, 1977), Bzs-5 (47.3 m); (f) Riyadella sp., Bzs-5 (47.3 m); (g) Trocholina conica (Schlumberger, 1898), Bzs-5 (32.0 m); (h) Trocholina palastiniensis Henson, 1948, Bzs-5 (26.5 m); (i) Protopeneroplis striata Weynschenk, 1950, Bzs-5 (18.1 m); (j) Callorbis minor Wernli \& Metzger, 1990, Bzs-5 (43.0 m); (k) Placopsilina sp., Bzs-5 (37.0 m); (1) Placopsilina sp., Bzs-5 (27.9 m); (m) Verneuilinoides sp., Bükkzsérc Quarry (Bed 14a); (n) Trochammina sp., Bükkzsérc Quarry (Bed 14a); (o) Mesoendothyra croatica Gušić, 1969, Bükkzsérc Quarry (Bed 13b); (p) Archaeosepta platierensis Wernli, 1970, Bükkzsérc Quarry (Bed 7); (q) Archaeosepta platierensis Wernli, 1970, Bükkzsérc Quarry (Bed 14a); (r) Protopeneroplis striata Weynschenk, 1950, Bükkzsérc Quarry (Bed 13a); (s) Labalina praecostata (Kassimova, 1971), Bükkzsérc Quarry (Bed 14a); (t) Trochammnina sp., Bükkzsérc Quarry (Bed 13b); (u) Labalina rawiensis (Pazdrowa, 1959), Bükkzsérc Quarry (Bed 20); (v) L. cf. quinqueloculinoides (Danitch, 1971), Bükkzsérc Quarry (Bed 9); (w) Placopsilina sp., Hódos-tetö; (x) Siphovalvulina sp., Hódos-tetö; (y) Redmondoides lugeoni (Septfontaine, 1977), Hódos-tetö; (z) Riyadella sp., Hódos-tetö; (aa) Callorbis minor Wernli \& Metzger, 1990, Hódos-tető; (bb) Protopeneroplis striata Weynschenk, 1950, Hódos-tető; (cc) Hauraniinae indet., Eregető E; (dd) Kilianina cf. blancheti Pfender, 1933, Eregető; (ee) Meyendorffina cf. bathoniana Aurouze \& Bizon, 1958, Eregetö; (ff) Mesoendothyra croatica Gušić, 1969, Eregetö; (gg) Labalina costata (Antonova, 1958b), Eregetö; (hh) Trocholina palastiniensis Henson, 1948, Eregetö; (ii) Protopeneroplis striata Weynschenk, 1950, Eregető; (jj) Callorbis minor Wernli \& Metzger, 1990, Pap-hegyes. 
(Fig. 12). The foraminifera fauna is characterized by the presence of Protopeneroplis striata, the TVT group and miliolinids.

Medium- to thin-bedded grey cherty limestone beds occur in the basal part of the quarry section. This interval is typified by peloidal grainstone with various amounts of ooids, cortoids and bioclasts. Fragments of thin-shelled bivalves ('filaments') are generally abundant; fragments of echinoderms and foraminifera (a few TVT, miliolinids) are usually present. This interval is overlain by a thick-bedded one that is made up of oolitic, peloidal grainstone (Figs 12a, 14), with common occurrence of echinoderm detritus and foraminifera-like Archaeosepta platierensis (samples 7-14), several miliolinids (Labalina rawiensis, L. occulta, L. praecostata, L. cf. quinqueloculinoides), the TVT group, Protopeneroplis striata and a few Callorbis minor, Haplophragmoides sp., Nodosaria spp. and Lenticulina spp. This is followed by a thinbedded interval with chert nodules that is characterized by radiolarian-filament wackestone. This in turn is overlain by another thick-bedded segment of peloidal grainstone texture. The topmost part of the section is again thin-bedded and cherty (Fig. 12b) with radiolarian wackestone-packstone texture. In these beds, the amount and the diversity of the foraminifera fauna strongly decrease.

Based on facies analysis of the approximately $50 \mathrm{~m}$ thick continuous succession, it is evident that the Bükkzsérc Limestone was accumulated at the toe of a carbonate platform foreslope and in a pelagic basin. Grains of the grainstone (ooids, cortoids, peloids and lithoclasts) were derived from a tropical carbonate platform and accumulated after redeposition in a toeof-slope environment. The grainstone textures refer to a high-energy, probably current-controlled depositional environment, although the grading that is a typical feature of turbidites is only scarcely visible. The habitat of most of the foraminifera found in these beds was the inner platform (Siphovalvulina sp., Mesoendothyra croatica, Labalina rawiensis, Trocholina conica and T. palastiniensis) or the outer platform (e.g. Gutnicella spp., Protopeneroplis striata and Archaeosepta platierensis); the latter is commonly referred to as 'threshold facies' (e.g. Gušić, 1969; Wernli, 1970; Septfontaine, 1981; Haas et al. 2006). The calcimicrobes may have occupied the platform and the upper slope. Crinoid meadows developed mostly on the slope terraces may have provided the crinoid detritus. The thinshelled bivalves and some of the foraminifera (Labalina praecostata, Trochammina spp.) were inhabitants of the toe-of-slope and deeper open shelf (Clerc, 2005). The radiolarian-rich facies were formed in a pelagic basin.

It must be emphasized that we found only subordinate amounts of terrigenous extraclasts in the Bükkzsérc Limestone. They are made up almost exclusively of platform-derived carbonates, pelagic carbonates and biogenic siliceous components. The carbonate grains were usually transported and redeposited as individual grains (ooids, cortoids, bioclasts, etc.) suggesting a coeval active carbonate platform in the neighbourhood of the depositional area, due to relatively rapid cementation of the tropical platform sediments.

\section{3.d. Summary of sedimentological characteristics and genetic interpretation of the studied succession}

Siliciclastic turbidites of the Lökvölgy Formation were exposed in the deepest part of core Bzs-11. These beds were deposited by low-density turbidity currents in an outer fan setting. The radiolarian-bearing shale intercalation represents a basin plain setting.

The overlying Oldalvölgy-Csipkéstetö Formation can be interpreted as a hemipelagic succession; the predominant part of the carbonate content may have been derived from a carbonate platform. The peloidal grainstone interbeds containing platform-derived foraminifera were deposited via low-density turbidity currents.

Core Bzs-11 exposed three breccia intervals within the Oldalvölgy-Csipkéstetö Formation, which are made up predominantly of centimetre-sized clasts of volcanic rocks: andesite in the deepest and thickest bed and basalt in the higher, thinner beds. The age of the clasts is unknown, most probably Triassic, similar to that of the dated volcanic clasts in the higher part of the succession (Haas et al. 2011). The coarse clast-supported breccia may be interpreted as rock fall or mass gravity flow deposits, formed at the base of relatively steep slopes. The appearance of the coarse-grained gravity mass-flow deposits suggests the initiation of intense tectonic movements, probably the onset of nappe stacking.

Coarse calcarenite to fine calcirudite beds with polymictic lithoclasts and redeposited platform-derived bioclasts and ooids characterize the basal part of the Mónosbél Formation. In these beds, volcanic components are common and coarser-grained volcaniclastic interbeds also occur (cores Bzs-11, -10 and in some outcrops; Table 1; Fig. 15). The volcanic material is extremely variable, including clasts of andesite, dacite, rhyolite and rarely basalt. According to recent preliminary radiometric age data, the acidic volcanites are of early Late Triassic age (Haas et al. 2011).

In the lithoclastic beds of the investigated outcrops (Fig. 3), carbonate clasts are usually predominant (Table 1; Fig. 15). Based on their microfacies characteristics and in some cases their microfossil content, the limestone clasts were derived from previously deposited and already consolidated Jurassic formations: mostly from toe-of-slope (e.g. redeposited oolitic packstone, peloidal grainstone) and basinal ('filament' wackestone, sponge spicule wackestone, radiolaria wackestone) facies and rarely from carbonate platform (e.g. ostracodal wackestone) facies. The radiolarite clasts were probably also derived from Jurassic basinal facies. Triassic-Lower Jurassic carbonates also occur. Clasts derived from siliciclastic formations (silty claystone, siltstone, fine- to medium-grained quartz sandstone) are also common. These clasts probably 


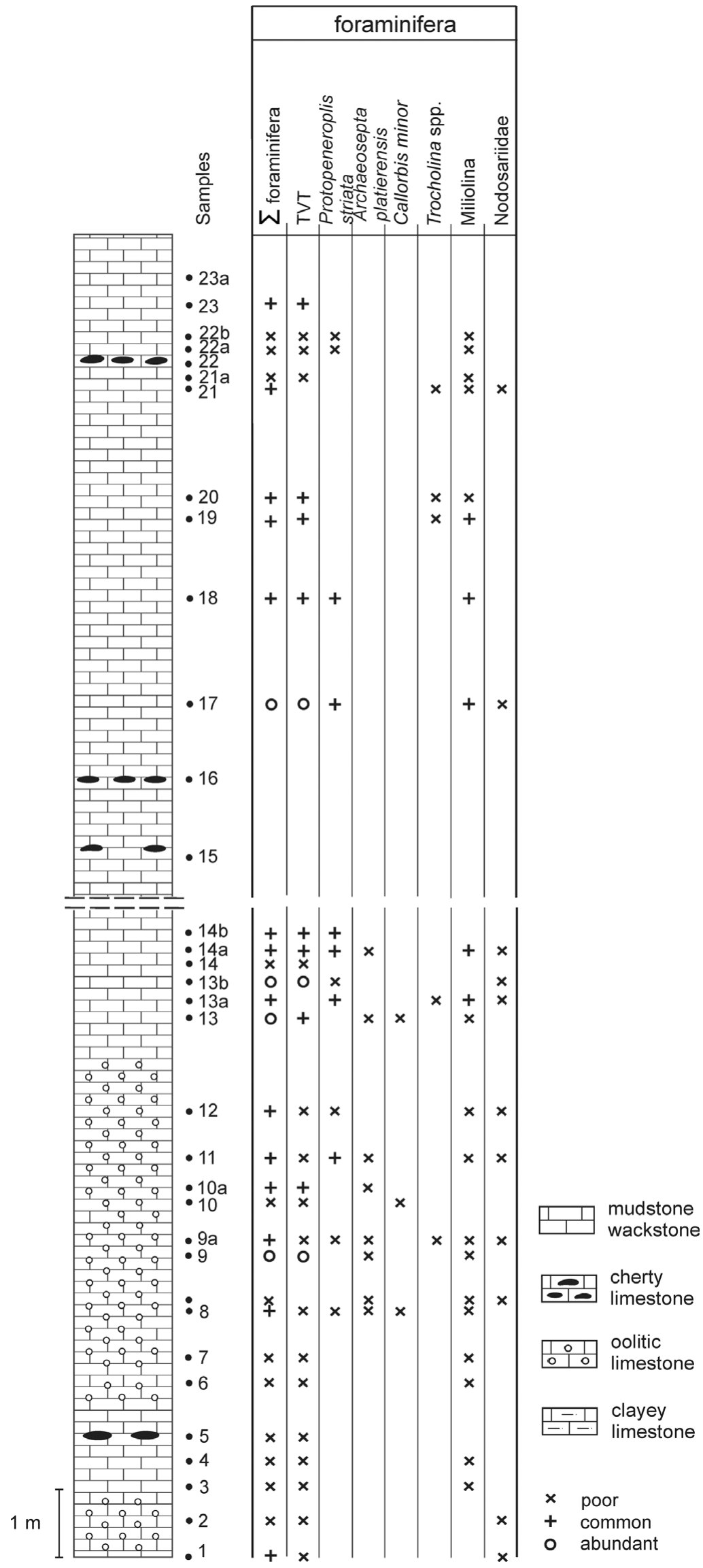

Figure 14. Lithology and distribution of foraminifera in the section of the Bükkzsérc Quarry. 

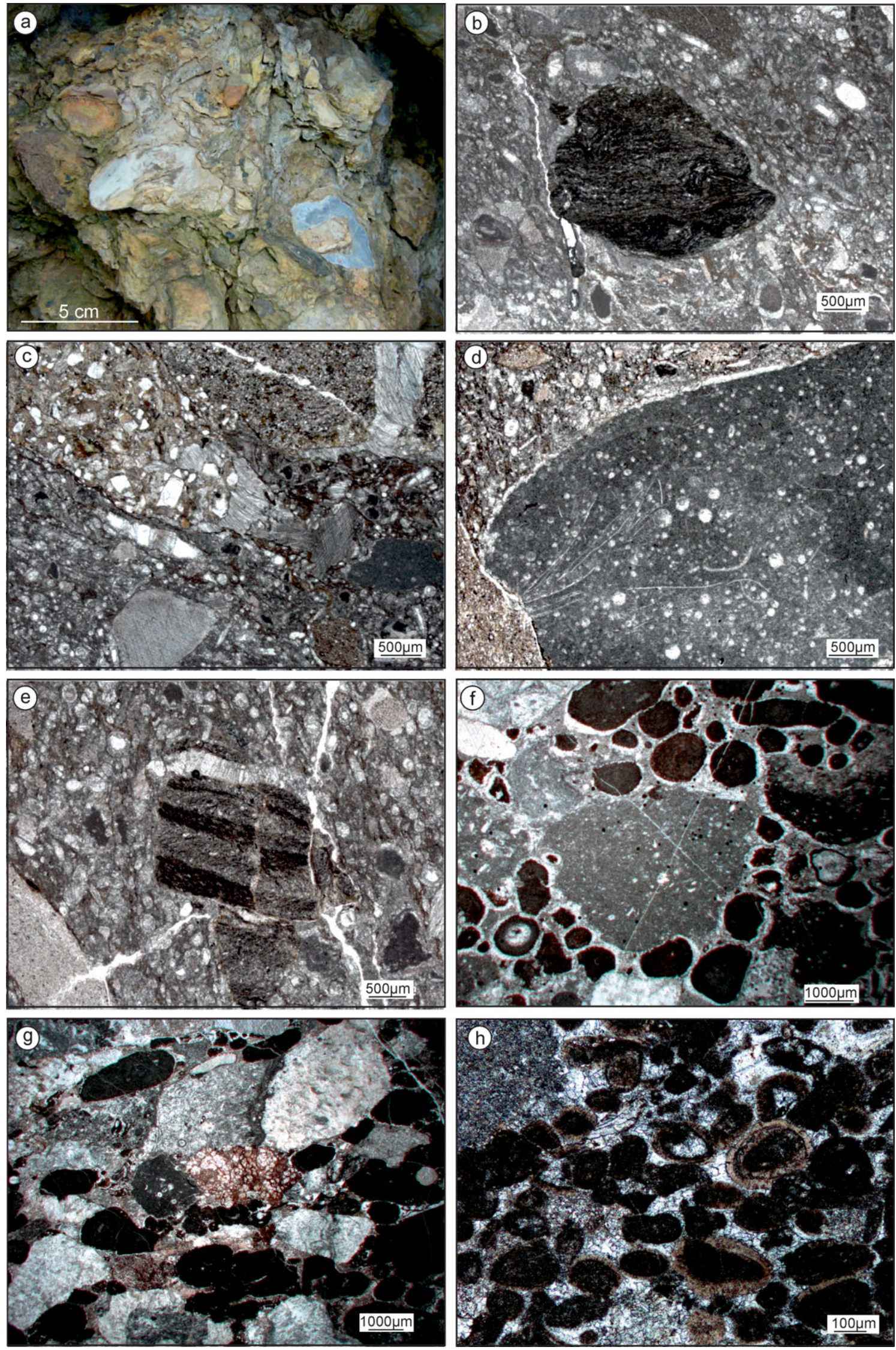

Figure 15. (Colour online) Typical clastic components of olistostromes in various outcrop occurrences. (a) Mud-supported, coarsegrained polymict conglomerate (debrite), Meredek-lápa. (b) Bioclastic limestone with a phyllite extraclast, Meredek-lápa. (c) Polymict lithoclastic, bioclastic packstone, Meredek-lápa. (d) Gravel-sized radiolarian-'filament' wackestone clast (probably Triassic), Meredeklápa. (e) Bioclastic, limestone with a phyllite extraclast, Hódos-tető. (f) Lithoclastic, oncoidal packstone, Solymos. (g) Lithoclastic, oncoidal packstone, Pap-hegyes. (h) Oolitic grainstone, Pap-hegyes. 


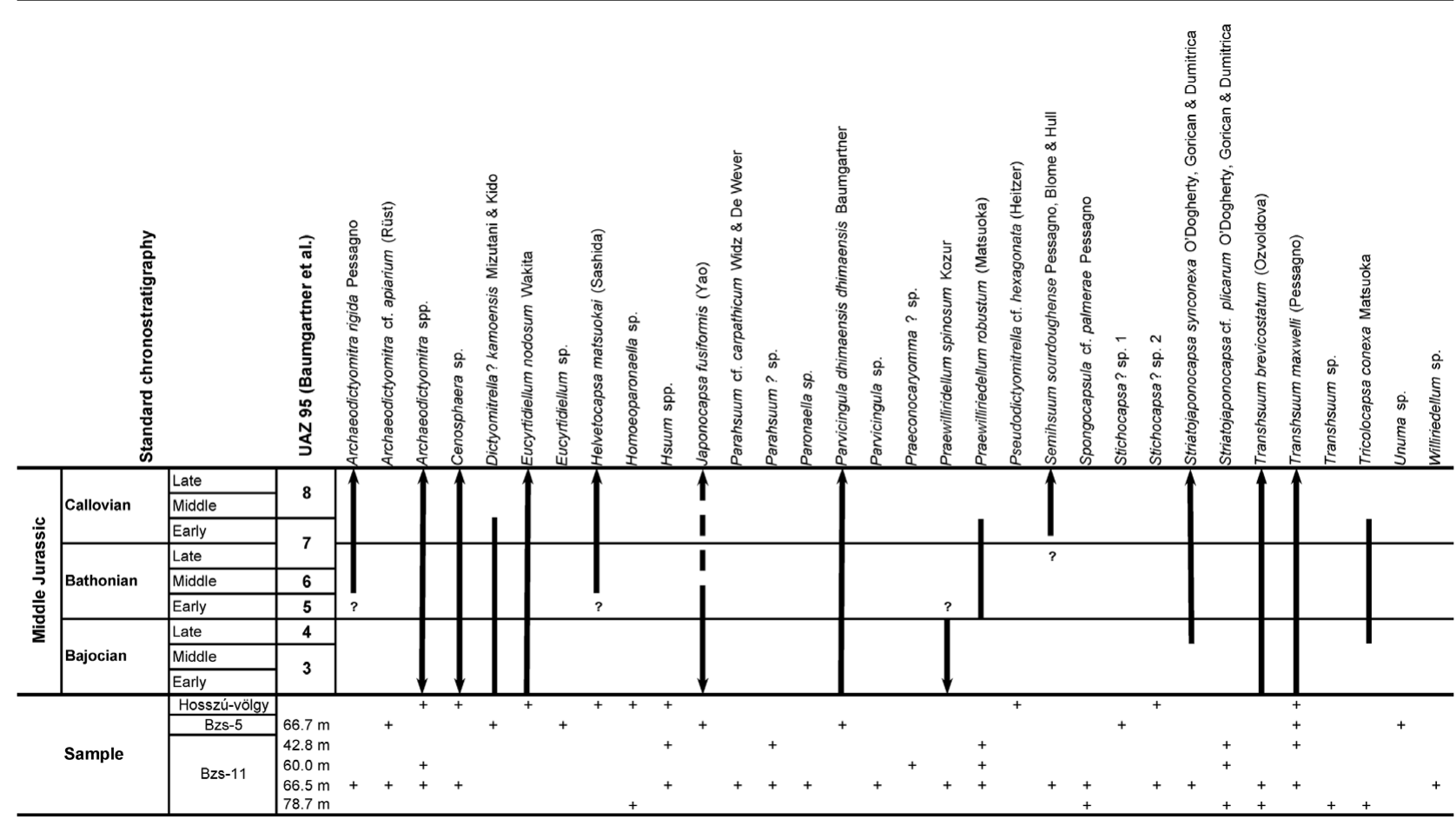

Figure 16. Stratigraphic distribution and occurrences of the identified radiolarians in the studied samples.

derived from the Jurassic succession, since similar rock types are known in the study area (Lökvölgy Formation, Vaskapu Sandstone Formation). There are smaller and larger magmatic clasts derived from ophiolite as well as from acidic and intermediate magmatites. Clasts of phyllite and mica slate also occur, but rarely. The ages of these components are not known.

The rock types described above can be interpreted as mass-flow deposits containing millimetreto centimetre-sized components derived from various sources. Some components were derived from metamorphic rocks; there are clasts originated from Triassic volcanites and shallow marine carbonates as well as from Jurassic rocks of basinal and platform foreslope facies. These sedimentological features suggest nappe stacking; the accreted nappes contained slightly metamorphosed slices and unmetamorphosed Triassic and Jurassic formations. Moreover, the platform-derived individual carbonate grains among the polymictic lithoclasts clearly indicate redeposition from a coeval carbonate platform. The mass-flow deposits (olistostromes) formed slope aprons along the front of the thrust belt. In the later stage of basin evolution, the size of the clasts increased and olistoliths of the Bükkzsérc Limestone became predominant in the upper part of the Mónosbél Formation. The large blocks may have been derived from out-of-sequence nappes of the previous platform foreland.

\section{Biostratigraphy and chronostratigraphy}

The biostratigraphy of the Mónosbél Group is based on radiolarians and foraminifera.

\section{4.a. Radiolarian biostratigraphy}

Radiolarians of Middle and Upper Jurassic formations have been investigated since the nineteenth century. In spite of this, their biostratigraphic interpretation is still questionable, because only a small proportion of radiolarian taxa have stratigraphic ranges that are constrained by other stratigraphically important fossils (e.g. Goričan, 1994; Baumgartner et al. 1995; Kozur, Mock \& Ožvoldová, 1996; Suzuki \& Gawlick, 2003; Beccaro, 2004, 2006; O'Dogherty et al. 2005).

The age of the Bányahegy Radiolarite is of critical importance for the evaluation of the Jurassic successions. Therefore, new sampling was carried out on the Bányahegy Radiolarite exposed in the Hosszúvölgy road-cut section on the eastern slope of Odvasbükk-tetö (Fig. 3). This sample yielded numerous unidentifiable radiolarian shells and a few poorly preserved ones. Based on the presence of Helvetocapsa matsuokai and Transhsuum maxwelli, this assemblage could be assigned to Unitary Association Zones 95 (UAZ95) 3-10, providing a very wide age range from the Early-Middle Bajocian to Late Oxfordian-Early Kimmeridgian (Fig. 16).

On the eastern slope of Odvas-bükk-tetö, the Bányahegy Radiolarite is overlain by the Lökvölgy Formation and then the Oldalvölgy-Csipkéstetö Formation (Figs 3, 4). In core Bzs-11, determinable radiolarians were found in four samples taken from the Oldalvölgy-Csipkéstetô Formation. The lowermost sample $(78.7 \mathrm{~m})$ contained a poorly preserved and lowdiversity radiolarian fauna (Figs 16, 17). The sample $66.5 \mathrm{~m}$ yielded a moderately well-preserved and diversified fauna (Fig. 16). Sample $60.0 \mathrm{~m}$ contained 


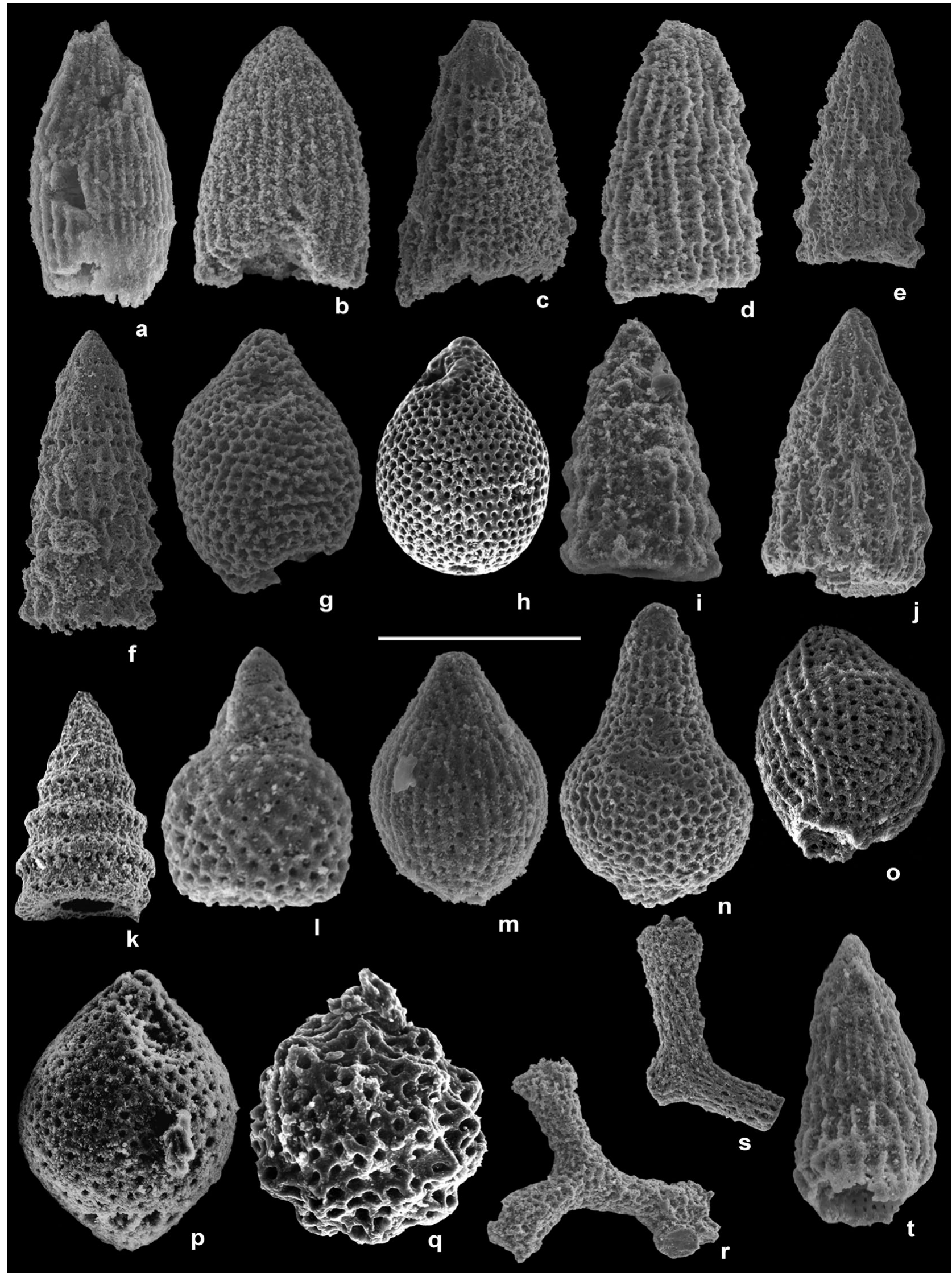

Figure 17. Radiolarians from core Bzs-11 and Hosszú-völgy outcrop: (a) Archaeodictyomitra rigida Pessagno, 1977, Bzs-11 (66.5 m), scale bar $=100 \mu \mathrm{m}$; (b) Archaeodictyomitra cf. apiarium (Rüst, 1885), Bzs-11 (66.5 m), scale bar=100 $\mu \mathrm{m}$; (c) Parahsuum cf. carpathicum Widz \& De Wever, 1993, Bzs-11 (66.5 m), scale bar $=100 \mu \mathrm{m}$; (d) Parahsuum? sp., Bzs-11 (42.8 m), scale bar = $85 \mu \mathrm{m}$; (e, f) Transhsuum brevicostatum (Ožvoldová, 1975), Bzs-11 $(66.5 \mathrm{~m})$, scale bar $=200 \mu \mathrm{m}$; (g) Praewilliriedellum robustum (Matsuoka, 1984), Bzs-11 (66.5 m), scale bar = $165 \mu \mathrm{m}$; (h) Praewilliriedellum robustum (Matsuoka, 1984), Bzs-11 (78.7 m), scale bar $=160 \mu \mathrm{m}$; (i) Transhsuum sp., Bzs-11 (66.5 m), scale bar = $185 \mu \mathrm{m}$; (j) Semihsuum sourdoughense Pessagno et al. 1993 , Bzs-11 
a poorly preserved and low-diversity radiolarian fauna (Fig. 16) with Praewilliriedellum robustum, which probably indicates UAZ95 5-7. The sample taken from $42.8 \mathrm{~m}$ indicates UAZ95 5-7 (Baumgartner et al. 1995) based on the co-occurrence of P. robustum and Transhsuum maxwelli.

According to Baumgartner et al. (1995) UAZ95 57 correspond to an Early Bathonian-Early Callovian age. Beccaro (2006) established a new, better-defined radiolarian biozonation for the Middle and Late Jurassic epochs, where the UAZ95 6-7 correspond to UAZ-SA A-B, which were assigned to the (?Early)Middle Bathonian to Early Oxfordian. The top of the UAZ-SA B is not directly constrained by stratigraphically important fossils but it must be older than Middle Oxfordian, owing to the precise age assignment of UAZ-SA C (Beccaro, 2006). According to the detailed biostratigraphic works of Suzuki \& Gawlick (2003) and Auer et al. (2009) UAZ-SA AB corresponds approximately to the Eucyrtidiellum unumaense and the lower part of the Protunuma lanosus radiolarian zones set up in the Northern Calcareous Alps. In summary, according to the radiolarian data, the Oldalvölgy-Csipkéstető Formation in core Bzs-11 is most probably Bathonian (?Early Callovian) in age.

In core Bzs-5 only one sample taken from $66.7 \mathrm{~m}$, probably representing the Oldalvölgy-Csipkéstetö Formation, contained a moderately to poorly preserved radiolarian fauna. It is characterized mostly by nassellarians (Fig. 16). According to Kozur (1984), Japonocapsa fusiformis occurs in the Bajocian-Lower Bathonian of the Bükk Mountains. However, this species was also reported from the Aalenian (Suzuki $\&$ Ogane, 2004) and with uncertainties (cf. and aff.) from the lowermost Oxfordian (Missoni et al. 2005). This range roughly corresponds to the Eucyrtidiellum unumaense Middle Jurassic radiolarian zone of Suzuki \& Gawlick (2003) and Auer et al. (2009).

\section{4.b. Foraminifera biostratigraphy}

Previously, Bérczi-Makk studied the foraminifera fauna of cores Bzs-5, -10 and -11 , and some outcrops (in Bérczi-Makk \& Pelikán, 1984; Bérczi-Makk, 1999). She found foraminifera in only a single level in core Bzs-10 and in two levels in core Bzs-11. From the latter core, Bérczi-Makk illustrated Lenticulina spp., which she defined as various species of the genus Epistomina (Bérczi-Makk, 1999, pl. X, fig. 1) and assigned these samples to the Bathonian-Callovian.
She identified the recrystallized miliolinids (Labalina spp., Ophthalmidium spp.) as Involutina bükki or as Spirillina sp. (e.g. Bérczi-Makk, 1999, pl. XI, fig. 1) from core Bzs-10 as well as from an outcrop at Odvasbükk-tető (Bérczi-Makk \& Pelikán, 1984). Based on the ambiguous identification of Planularia? (e.g. Bérczi-Makk, 1999, pl. XI, fig. 4) and Lingulina nodosaria (e.g. Bérczi-Makk, 1999, pl. XI, fig. 5), she assigned these beds to the Callovian-Oxfordian. From Meredek-lápa, Mesoendothyra cf. croatica was reported by Bérczi-Makk \& Pelikán (1984, p. 142), although the location of the sample is somewhat ambiguously indicated on plate III. Otherwise, the illustrated specimens (pl. III, figs 5, 7) that were assigned to Paalzowella $\mathrm{cf}$. turbinella belong to the genus Siphovalvulina, suggesting a Middle Jurassic age. In core Bzs-5, Bérczi-Makk (1999) recognized a Gutnicella gr. cayeuxi horizon and the appearance of Protopeneroplis striata above it. Referring to the work of Allemann \& Schroeder (1975), who assigned this species to the Bajocian-Bathonian, she classified the entire succession of core Bzs-5 and the Bükkzsérc Quarry (referred to as Patkó cliff, Bükkzsérc) to the Bathonian-Callovian. It must be noted that the cited data are rather uncertain and the age assignment is unique in the literature.

The study of the foraminifera fauna in the succession exposed by core Bzs-11 led to important new results. It is particularly important that we found foraminifera (Labalina rawiensis, Labalina sp., Nodosaria sp. and Cylindrotrocholina excels) in the lower sandstoneshale interval that was assigned to the Lökvölgy Formation in core Bzs-11. These forms suggest a Middle Jurassic (Early Bajocian-Early Bathonian) age (Ruggieri \& Giunta, 1965; Clerc, 2005).

The co-occurrence of Mesoendothyra croatica, Labalina rawiensis, L. costata, L. occulta, Ophthalmidium caucasicum and Trocholina palastiniensis in the overlying limestone-radiolarite interval (Oldalvölgy-Csipkéstető Formation), both in cores Bzs-10 and -11, suggests a Middle Jurassic (probably Early Bajocian-Early Bathonian) age (Fig. 18; Derin \& Reiss, 1965; Gutnic \& Moullade, 1967; Septfontaine, 1974, 1978, 1981; Sotak, 1987; Heinz \& Isenschmidt, 1988; Banner, Simmons \& Whittaker, 1991; Chiocchini \& Mancinelli, 1996; Bassoullet, 1997; Clerck, 2005; Velić, 2007).

In the upper part of cores Bzs-10 and -11, Late Triassic and Early and Middle Jurassic foraminifera faunas (similar, but poorer than below) were found in

(66.5 m), scale bar = $185 \mu \mathrm{m}$; (k) Dictyomitrella? kamoensis Mizutani \& Kido, 1983, Bzs-5 (66.7 m), scale bar = $100 \mu \mathrm{m}$; (1) Eucyrtidiellum nodosum Wakita, 1988, Hosszú-völgy, scale bar $=180 \mu \mathrm{m}$; (m) Helvetocapsa matsuokai (Sashida, 1988), Bzs-11 $(66.5 \mathrm{~m})$, scale bar $=125 \mu \mathrm{m}$; (n) Stichocapsa? sp. 1, Bzs-11 $(66.5 \mathrm{~m})$, scale bar $=175 \mu \mathrm{m}$; (o) Striatojaponocapsa synconexa O'Dogherty, Gorican \& Dumitrica, 2005, Bzs-11 (66.5 m), scale bar $=175 \mu \mathrm{m}$; (p) Japonocapsa. fusiformis (Yao, 1979), Bzs$11(60.0 \mathrm{~m})$, scale bar $=135 \mu \mathrm{m}$; (q) Praeconocaryomma? sp., Bzs-11 $(60.0 \mathrm{~m})$, scale bar $=100 \mu \mathrm{m}$; (r) Paronaella sp., Bzs-11 $(66.5 \mathrm{~m})$, scale bar $=200 \mu \mathrm{m}$; (s) Homoeparonaella sp., Hosszú-völgy, scale bar $=200 \mu \mathrm{m}$; (t) Williriedellum sp., Bzs-11 (66.5 m), scale bar $=190 \mu \mathrm{m}$. 


\begin{tabular}{|c|c|c|c|c|c|c|c|c|c|c|}
\hline \multirow{2}{*}{ Species } & \multirow[b]{2}{*}{ Aalenian } & \multicolumn{3}{|c|}{ Bajocian } & \multicolumn{3}{|c|}{ Bathonian } & \multicolumn{3}{|c|}{ Callovian } \\
\hline & & \begin{tabular}{|l|}
$E$ \\
\end{tabular} & \begin{tabular}{l|l}
$M$ \\
\end{tabular} & $\bar{L}$ & \begin{tabular}{|l|}
$E$ \\
\end{tabular} & \begin{tabular}{l|l}
$\mathbf{M}$ & \\
\end{tabular} & $\bar{L}$ & $E$ & $\mathbf{M}$ & $\mathrm{L}$ \\
\hline \multicolumn{11}{|l|}{ Gutnicella gr. cayeuxi } \\
\hline \multicolumn{11}{|l|}{ Meyendorffina bathonica } \\
\hline \multicolumn{11}{|l|}{ Kilianina blancheti } \\
\hline \multicolumn{11}{|l|}{ Callorbis minor } \\
\hline \multicolumn{11}{|l|}{ Archaeosepta platierensis } \\
\hline \multicolumn{11}{|l|}{ Protopeneroplis striata } \\
\hline \multicolumn{11}{|l|}{ Mesoendothyra gr. croatica } \\
\hline \multicolumn{11}{|l|}{ Redmondoides gr. lugeoni } \\
\hline \multicolumn{11}{|l|}{ Labalina costata } \\
\hline \multicolumn{11}{|l|}{ Labalina occulta } \\
\hline \multicolumn{11}{|l|}{ Labalina praecostata } \\
\hline \multicolumn{11}{|l|}{ Labalina rawiensis } \\
\hline \multicolumn{11}{|c|}{ Labalina quinqueloculinoides } \\
\hline \multicolumn{11}{|c|}{ Ophthalmidium caucasicum } \\
\hline \multicolumn{11}{|l|}{ Ophthalmidium obscurum } \\
\hline \multicolumn{11}{|l|}{ Ophthalmidium terquemi } \\
\hline \multicolumn{11}{|l|}{ Trocholina conica } \\
\hline Trocholina palastiniensis & & & & & & & & & & \\
\hline
\end{tabular}

Figure 18. Stratigraphic distribution of the most important taxa of the studied section based on Banner, Simmons \& Whittaker (1991), Bassoullet (1997), Chiocchini \& Mancinelli (1996), Clerck (2005), Derin \& Reiss (1965), Heinz \& Isenschmidt (1988), Gutnic \& Moullade (1967), Septfontaine (1974, 1978, 1981), Sotak (1987) and Velić (2007).

the polymictic olistostrome horizons. The Late Triassic and Early Jurassic faunas occur in carbonate lithoclasts while the Middle Jurassic elements redeposited from unconsolidated sediment may be roughly coeval with the deposition of the olistostrome beds. Above the top of the core sections, blocks of the Bükkzsérc Limestone were mapped on the higher part of the slope of Odvasbükk-tető, which contains Middle Jurassic faunas (i.e. Trocholina cf. palastiniensis, Protopeneroplis striata) in contrast to the previous Toarcian age dating for this locality (Bérczi-Makk \& Pelikán, 1984).

In the type locality of the Bükkzsérc Formation the oldest layers (core Bzs-5, 51.9-45.0 m) are characterized the presence of the Aalenian-Early Bajocian Gutnicella gr. cayeuxi. Protopeneroplis striata was found above it (at $43.0 \mathrm{~m}$ ). Both are characteristic forms of the outer platform environments (e.g. Septfontaine, 1981), but according to the relevant literature they never occur in the same stratigraphic level (e.g. Dufaure, 1958; Raffi \& Forti 1959; Radoičič, 1966, 1987; Gutnic \& Moullade, 1967; Crescenti, 1969, 1971; Velić, 2007). Co-occurrence of these two species in breccia beds of Bey Dağlari, Taurus, Turkey (Bassoullet \& Poisson,
1975) as well as in similar rocks in Iraqi Kurdistan (Radoičič, 1987) can be explained by sedimentological reasons, i.e. reworking of the older elements in clasts.

We have to note that there is only one uncertain record of the presence of the Gutnicella group in Upper Bajocian strata (Dufaure, 1958) and only very doubtful data are available on the occurrence of Protopeneroplis in Aalenian strata (Ferrari, 1962; Brun, 1968). There is no unambiguous record of this species from Lower Bajocian strata. Based on these facts, Gutnicella gr. cayeuxi indicates an Aalenian-Early Bajocian age, while the first occurrence of the genus Protopeneroplis can be dated to the late Early Bajocian. Thus, the disappearance of the Gutnicella group and the appearance of Protopeneroplis striata and Callorbis minor at about $43.0 \mathrm{~m}$ in core Bzs-5 would indicate the beginning of the Middle Bajocian (Humphriesianum Zone).

The appearance of Archaeosepta platierensis in Bed 7 in the Bükkzsérc Quarry indicates the beginning of the Late Bajocian. Based on the co-occurrence of $A$. platierensis, Callorbis minor and Labalina praecostata in Bed 13, this layer is older than Bathonian, most 
probably Late Bajocian. In Beds 15-23 there are no suitable age indicator foraminifera. Based on the presence of the earliest Bajocian to latest Callovian Labalina rawiensis up to Bed 21, only a Late Jurassic age for this interval can be excluded.

An assemblage characterized by Protopeneroplis striata and Callorbis minor similar to that in 43-32 m of core Bzs-5 was recognized in lithoclastic beds in the Hódos-tetö and Pap-hegyes localities (Figs 3, 13). These forms indicate a Middle to Late Bajocian age.

In the samples from Eregeto", Late Bathonian complex agglutinated forms like Meyendorffina cf. bathonica and Kilianina cf. blancheti were recognized; this is the youngest assemblage found in the study area. The presence of the larger orbitolinids Gutnicella, Meyendorffina and Kilianina indicate continuous carbonate platform development during the (Aalenian)-Early Bajocian-Late Bathonian interval in the proximity of the depositional area of the Mónosbél Group.

\section{4.c. Chronostratigraphic interpretation}

There are uncertainties in the structural model, which influence the assumed relationships of the lithostratigraphic units, and there are uncertainties in the radiolarian and foraminifera biostratigraphy as well; thus, the construction of a coherent chronostratigraphic scheme is not easy. Based on our studies the following interpretation can be outlined. Evaluation of the new radiolarian data allowed a very wide age range for the Bányahegy Radiolarite from the Early Bajocian to the Early Kimmeridgian. If a younger age (younger than Bajocian) is valid, we must find a tectonic solution as was proposed by Csontos (2000). However, if the Bányahegy Radiolarite is Early Bajocian in age, a continuous succession from the Bányahegy Radiolarite through the Lökvölgy Formation to the Mónosbél Group cannot be excluded either (see Fig. 4). We have a few foraminifera biostratigraphic data from the upper part of the Lökvölgy Formation suggesting an Early Bajocian to Early Bathonian age. Based on the foraminifera fauna in core Bzs-11, the OldalvölgyCsipkésteto" Formation can be assigned to the Early Bajocian-Early Bathonian as well. Taking into account all of these data, the age of the Oldalvölgy-Csipkésteto Formation is Bathonian, probably Early Bathonian (Fig. 4).

Radiolarians found at $66.7 \mathrm{~m}$ in core Bzs-5 indicate an Early Bajocian to Early Bathonian age. However, this fauna was derived from breccia grains. Consequently the depositional age of the breccia bed, which is assigned to the Mónosbél Group, is probably Bathonian in age.

Based on the foraminifera fauna, the age of the Bükkzsérc Limestone in core Bzs-5 is (Aalenian?)Early Bajocian. This age date suggests that the Bükkzsérc Limestone is present here as a block (or blocks) within the Mónosbél Group (Fig. 4). The age range of the Bükkzsérc Limestone encompasses the (Aalenian?) Early Bajocian to the Late Bajocian.
According to the foraminifera fauna encountered in the sample from Eregeto E, the deposition of the lithoclastic beds (Mónosbél Formation) continued at least until Late Bathonian time (Fig. 4).

\section{Relationships}

In northeastern Hungary (Darnó Unit and Rudabánya Hills) and southeastern Slovakia (Meliata Unit), Middle to Upper Jurassic polymictic redeposited gravity deposits and ophiolite mélange complexes are known that show more or less similar features to those in the southwestern Bükk Mountains. They can be interpreted as tectonically transported, dispersed elements of the Neotethys suture zone (e.g. Pamić, 1997; Haas \& Kovács, 2001; Dimitrijevic et al. 2003; Haas et al. 2006, 2011) (Fig. 1).

The Mónosbél Group extends over the limits of the study area in the Bükk Mountains and continues into the Darnó area (Fig. 1). It was also recognized in ore exploratory wells in the basement of a Tertiary sedimentary and volcanic complex in the Mátra Mountains (Haas et al. 2006, 2011; Kovács et al. 2007). Olistoliths of marine Upper Permian and Upper Triassic Hallstatt Limestone were encountered here within Bajocian to Callovian shale and radiolarite. The thickness of the olistostrome-rich intervals may exceed $100 \mathrm{~m}$. The usually matrix-supported breccia is made up mostly of radiolaria-bearing silicified rock types (radiolarian wackestone and packstone, radiolarite). However, a thin intercalation with redeposited oolite and oncoid grains was also encountered in a studied core section (Haas et al. 2011). In a borehole (Rm-109) drilled near Kékes Peak (Mátra Mountains), Bajocian platform-derived redeposited carbonates, more proximal than those in the Bükk Mountains, were encountered in a thickness of more than $200 \mathrm{~m}$ (Haas et al. 2006).

Olistostrome, graded calcarenite and mixed siliciclastic-carbonate sandstone beds were recently found on the southern slope of Csipkés Hill, Rudabánya Hills, northeast of the Bükk Mountains (Fig. 1) (Kövér et al. 2009). The foraminifera assemblage (Callorbis minor, Protopeneroplis striata, Planiinvoluta sp., Trochammina sp, Siphovalvulina sp., Tubinella? sp.) found in the matrix of graded turbiditic beds is similar to that found in the Bükkzsérc Limestone. The upper part of the section contains olistostrome horizons. The olistostromes are grain-supported, containing clasts from $1-2 \mathrm{~mm}$ to $40-50 \mathrm{~mm}$ in size. Typical components are Middle Triassic grey platform carbonates (Steinalm Limestone), Middle and Upper Triassic red cherty limestone of basin facies (Bódvalenke Formation) and Upper Triassic pink and grey limestone of basin facies (Hallstatt Limestone) (Kövér et al. 2009).

There are two important occurrences of the Meliata Unit in southeastern Slovakia (Faryad, 1999) (Fig. 1.). Near the village of Meliata, dark shale with radiolarite, sandstone and olistostrome intercalations occurs. Based on radiolarians, the age of the radiolarite 
interbeds is Middle Bathonian to Early Oxfordian (Kozur, Mock \& Ožvoldová, 1996). Large blocks (olistoliths) of Triassic rocks and Triassic and Jurassic radiolarite commonly occur in the shale matrix. The olistostromes contain mostly carbonate clasts (Carnian grey cherty limestone, Carnian and Norian limestone), but red radiolarian chert clasts also occur (Mock et al. 1998). In some breccia beds the basalt clasts are predominant (Mock et al. 1998).

The other important occurrence of the Meliata Unit is located near to the village of Jaklovce. Here the mélange is made up mostly of olistoliths of various sizes, whereas the sandstone to microbreccia and olistostrome intercalations are less common in the Middle Jurassic dark shale matrix (Kozur \& Mock, 1995). The blocks consist of light, probably shallow marine, slightly metamorphosed limestone, siliciclastic rocks, pelagic cherty limestone, dolomite, radiolarite, rhyolite, basalt and serpentinite. AalenianBajocian and Callovian-Oxfordian radiolarian faunas were found in the red limestone, and radiolarite occurs above the basalt blocks (Aubrecht et al. 2010).

A strongly tectonized and partly reworked ophiolite mélange complex occurs in the northwestern part of Medvednica Mountains, southern part of Ivanščica Mountains, in the southeastern part of Samoborska Gora and in the central part of the Kalnik Mountains in Croatia, which were assigned to the Kalnik Unit (Fig. 1) (Haas et al. 2000). In the mélange complex, large blocks of basalt, gabbro, serpentinite, radiolarite and limestone of various facies and ages occur in a radiolarite and shale matrix (Pamić, 2003).

From the Medvednica Mountains, Triassic carbonate olistoliths and matrix-supported polymictic conglomerates containing clasts of Triassic radiolarian chert, Jurassic silicified shale and sandstone, basalt and ultramafic magmatic rocks were reported. Radiolarians found in the radiolarite matrix proved a latest BajocianEarly Bathonian to Late Bathonian-Early Callovian age for the mélange complex (Halamić et al. 1999; Halamić, Marchig \& Goričan, 2005). This lithofacies is very similar to those of the Mónosbél Formation in the Bükk as far as both the matrix and the components of the olistostromes are concerned; moreover their ages are also similar. In the Jurassic mélange complex of Kalnik Mountains the Triassic basalt olistoliths show definite genetic relationships with the Triassic volcanite bodies known in the Darnó area, North Hungary (Kiss, Molnár \& Palinkaš, 2008; Kiss et al. 2010).

In the Dinarides, ophiolite mélange complexes comparable to those in the Bükk area occur in the Dinaridic Ophiolite Belt (Fig. 1) (Dimitrijević et al. 2003). The ophiolite mélange contains fragments of obducted ophiolite (lherzolite), Triassic and Jurassic limestone olistoliths, and polymictic olistostromes. Carnian to Upper Jurassic radiolarian chert (Goričan, Karamata \& Batoćanin-Srećković, 1999; Vishnevskaya, Derić \& Zakariadze, 2009), greywacke, basalt, gabbro, ultramafic rocks, granite, and Triassic and Jurassic limestone are typical clastic components of the olistostromes. The Jurassic matrix is usually argillaceous, silty, less frequently sandy and locally radiolaritic (Karamata et al. 2000; Pamić, Tomljenović \& Balen, 2002; Dimitrijević et al. 2003; Karamata, 2006; Robertson, Karamata \& Šarić, 2009, Gawlick et al. 2009).

Many common sedimentological features of the Jurassic complexes discussed above can be limited to the processes of the Neotethys closure. However, owing to their different palaeo-position, the composition of the redeposited clasts shows significant differences depending on geologic features of the source area. The most striking difference is the common occurrence of the Middle Jurassic redeposited oolitic lithoclasts, olistoliths and individual ooids and platform-derived bioclasts in the olistostromes of the Bükk Mountains, which was not reported from Dinaridic olistostromes. However, Middle Jurassic bioclastic and oolitic carbonate turbidite interbeds were encountered in radiolarite of some exposures in the Dinaridic Ophiolite Belt (Haas et al. 2010).

\section{Jurassic geodynamic setting and related sediment deposition in the Bükk area in the frame of the western Neotethys evolution}

The Bükk Unit reached its present-day setting only during Tertiary time as a result of multiple largescale tectonic movements along the Mid-Hungarian Fault Zone, together with other fragments originating from various parts of the South Alpine and Dinaridic domains (e.g. Csontos et al. 1992; Csontos \& Nagymarosy, 1998; Fodor et al. 1999; Schmid et al. 2008; Kovács \& Haas, 2010). Its primary nappe stacking, regional metamorphism and folding took place during Late Mesozoic times, prior to the longdistance displacement of the unit. Consequently, the Alpine geodynamic evolution of the Bükk area and its tectonically controlled sediment deposition can be interpreted only within the framework of the evolution of the northwestern Neotethys realm.

The geodynamic and palaeogeographic interpretation of the northwestern Neotethys has been the subject of discussions for a long time. The key issue of the debate is the interpretation of the structural setting and evolution of the Dinaridic Ophiolite Belt. According to several authors it is the remnant of an in situ oceanic basin (e.g. Dimitrijević, 1997; Dimitrijević et al. 2003; Karamata, 2006) that can be correlated with the Pindos oceanic basin in the Hellenides (Robertson \& Shallo, 2000; Stampfli et al. 2001; Csontos \& Vörös, 2004; Karamata, 2006; Robertson, Karamata \& Sarić, 2009). According to other authors it is an ophiolite nappe, emplaced by westward obduction from the Vardar Zone (e.g. Bortolotti et al. 2005; Schmid et al. 2008; Gawlick et al. 2008). There is a crucial difference between the two models. In the former the Jadar, Drina-Ivanjica and other units were dismembered from the Adriatic margin as a result of the opening of the western oceanic basin (Dinaridic Ophiolite Belt), while in the latter 
they are tectonic windows exposing the distal Adriatic margin.

The metamorphic soles of the Dinaridic ophiolite formed during Middle to Late Jurassic time (based mostly on K-Ar dating of 147-174 Ma; Sprey et al. 1984; Karamata, 1985). The ophiolite and the associated mélange represent a subduction complex controlled by tectonic accretion and sedimentary redeposition (Robertson, Karamata \& Šarić, 2009). Collision of a subduction trench with a continental margin may have been the cause of the Jurassic ophiolite emplacement. However, parts of the western Neotethys Ocean (the Vardar Zone Western Belt Karamata, 2006; Sava Zone - Schmid et al. 2008) remained open until Late Cretaceous time; its closure was followed by regional-scale southward thrusting.

The Upper Palaeozoic to Triassic succession of the Bükk Mountains shows striking similarity to that of the Carnic Alps-Southern Karawanks, the Julian Alps, and the Sana-Una and Jadar blocks of the Dinarides (e.g. Protić et al. 2000; Filipović et al. 2003), suggesting that in Late Palaeozoic time they were located in the inner offshore zone of the Tethys, relatively close to each other. In Early Triassic time they were parts of a rather uniform marginal ramp typified by mixed siliciclastic and carbonate sedimentation that turned to carbonate deposition in the Anisian (Hips \& Pelikán, 2002). Neotethys rifting in Late Anisian to Early Ladinian time led to segmentation of this ramp; isolated platforms and grabens were formed (Velledits, 2000). These plate tectonic processes may have led to separation of the Adriatic-Dinaridic Carbonate Platform, where the shallow marine conditions continued throughout the Jurassic to Cretaceous period (Tišljar et al. 2002), and, at least according to some of the interpretations (e.g. Robertson, Karamata \& Saric, 2009), dismembering of large blocks from the Adriatic margin, the Jadar and the Bükk units among others.

The area of the Bükk Mountains was also subject to extensional tectonics and related volcanic activity in Late Anisian to Carnian time (Velledits, 2000). Carbonate platforms and intraplatform basins developed. During Late Triassic time, continuous extension led to tectonically forced backstepping and to drowning of the platforms that was completed by the end of the Triassic Period. In Early Jurassic time, the former platforms were transformed into submarine highs with only local, ephemeral sediment deposition. In Middle Jurassic time, the deepening continued and at some time during Middle or early Late Jurassic time, a radiolarite veneer was formed, covering both the previous platform and basin deposits. Then coarse- to fine-grained siliciclastic sediments (Vaskapu Sandstone) and distal siliciclastic turbidites (Lökvölgy Formation) were deposited in a deep-sea basin developed above the attenuated continental crust. Owing to the discussed uncertainties of the age of these formations, their spatial and temporal relationship with the Mónosbél Group is still not clear.
The composition of the Mónosbél Group is complex, reflecting its multi-stage depositional history. The oldest biostratigraphically dated element of the Mónosbél Group is the (Aalenian?) Lower to Upper Bajocian Bükkzsérc Limestone, although it must be kept in mind that these rocks are usually present as smaller or larger redeposited fragments. The large blocks would have slid down from the neighbouring area into the deep depositional basin in late Middle Jurassic time, most probably in Late Bathonian time. It must be noted here that beds containing fine, redeposited shallow marine carbonate grains (ooids, cortoids, peloids and bioclasts) are also present in the hemipelagic Oldalvölgy Formation, and in some olistostromes of the Mónosbél Formation, individual platform-derived grains were also found. These facts imply continuing shallow marine input during Middle Jurassic time, at least until Late Bathonian time.

The grains of the Bükkzsérc Limestone were formed on a carbonate platform; the redeposited particles were accumulated in the foreland of a platform foreslope. The Adriatic-Dinaridic Carbonate Platform (ADCP) is the only preserved large carbonate platform in the wider region that was active during Middle Jurassic time. Along with the previously discussed geodynamic constraints, we assume that the ADCP was the provenance of the Bükkzsérc Limestone. However, a hypothetical non-preserved platform as provenance cannot be excluded. In Middle Jurassic time mostly oolitic sediments were formed in the northeastern part of the ADCP (Dragičević \& Velić, 2002). In several places coeval slope and toe-of-slope facies of the ADCP were also preserved. During Late Bajocian to Bathonian time, a thick, redeposited oolitic limestone succession accumulated in the Belluno Trough at the northwestern end of the ADCP (Friuli Platform) (Bosellini, Masetti \& Sarti, 1981; Clari \& Masetti, 2002). At the same time, limestone containing carbonate lithoclasts and redeposited ooid grains was formed along the slope of the ADCP in the Slovenian Trough (surroundings of Tolmin), pinching out and interfingering with pelagic deposits northeastward (Rožič \& Popit, 2006; Rožič, 2009). Similar sequences were reported from Mt Žumberak, Croatia (Bucković, Tešović \& Gušić, 2004; Bucković, 2006) and further southeastward along the ADCP margin (Dragičević \& Velić, 2002). Textural features, microbiofacies and microfossils (e.g. foraminifera fauna) of these formations are very similar to those of the Bükkzsérc Limestone (Haas et al. 2006). Distal toe-of-slope and pelagic basin facies were found as intercalations within the Bükkzsérc Limestone (e.g. in the Bükkzsérc Quarry). These are similar to those facies, which are predominant in the Oldalvölgy-Csipkéstetö Formation. They imply a similar interfingering of the slope-related and basin facies reported from the Slovenian Trough (Rožič \& Popit, 2006).

According to our concept, deposition of toe-ofslope and proximal basin facies of the Bükkzsérc Limestone represents the passive margin evolutionary 
stage of the Adriatic (Apulian) margin of the western Neotethys during Bajocian time. Dismembered and drowned blocks of the former platforms were already deep pelagic basins, by that time far from the stillexisting platform.

The appearance of the polymictic gravity deposits (olistostromes), and later on large slid blocks (olistoliths), suggests the onset of the formation of accretionary complexes in the third stage of the evolution in Late Bathonian time. The compressive tectonic movements led to imbrication, stacking of thrust slices and uplifting and disruption of the previously deposited and already lithified periplatform carbonate deposits. In the course of the overthrusting movements, the older basement rocks may also have been exposed and subjected to erosion.

In the Bükk Unit, obduction may have taken place during Middle Jurassic to earliest Cretaceous time (Balla, 1987; Csontos, 2000) and led to development of a subduction-related mélange complex containing blocks of ophiolite and fragments of the Adriatic continental margin. Further compression resulted in the overthrust of the mélange complex onto the blocks dismembered earlier from the Adriatic margin, leading to regional metamorphism of the Upper Palaeozoic to Upper Jurassic formations in late Early Cretaceous (110-120 Ma) and Late Cretaceous (90 Ma) times (Árkai, Balogh \& Dunkl, 1995).

\section{Conclusions}

(1) Displaced elements of the Neotethys ophiolite mélange complex occur in the Bükk-Darnó area, in North Hungary. Study of the depositional facies and age determination of the subduction-related sedimentary formations on the one hand, and detailed petrographic analysis, facies interpretation and age determination of the clastic components of the mélange on the other, provided important data for detection of the origin of clastic material and reconstruction of a complex ocean closure history.

(2) In Middle Triassic time, the opening of the Neotethys Ocean led to differentiation of the previously uniform shallow marine Adriatic margin, and probably large blocks were dismembered from the marginal part of the later Adriatic-Dinaridic Carbonate Platform. The Bükk Unit may have been one of the dismembered blocks where the carbonate ramps/platforms were subject to drowning by the end of the Triassic Period. During Middle to earliest Late Jurassic time, after a long-lasting marine erosion and/or non-depositional period, a radiolarite veneer was formed under deep-sea conditions over the shallow- and on the deep-marine Triassic carbonates. This was followed by deposition of siliciclastic gravity successions. However, the relationship between this sequence and the overlying Mónosbél Group is still uncertain; it is either continuous or tectonic (overthrust contact).

(3) The Bükkzsérc Limestone is a peculiar formation of the Jurassic of the Bükk Mountains that occurs mostly in the form of redeposited clasts and slid blocks. The limestone is typically made up of redeposited platform-derived grains, which were deposited in a toeof-platform foreslope and periplatform basin setting during (?Aalenian) Early to Late Bajocian time.

(4) Showing a general coarsening-upward trend, the Mónosbél Group was formed in subduction-related basins. Based on radiolarians and foraminifera in the matrix of olistostrome interbeds, the formations of the Mónosbél Group were most probably deposited during Bathonian time. In the lower part of the group (Oldalvölgy-Csipkéstetö Formation), pelagic carbonates, shale and radiolarite prevail. The higher part of the succession is characterized by polymictic olistostromes (Mónosbél Formation). Large olistoliths that are predominantly blocks of the Bükkzsérc Limestone appear in the upper part of the sequence.

(5) The appearance of the polymictic olistostromes with shallow- and deep-marine carbonate, siliciclastic, basic to acidic volcaniclastic and metamorphic components implies stacking of thrust slices in a compressional regime, probably in Late Bajocian time. This was followed by input of large slid blocks, mostly of the Bükkzsérc Limestone. The common occurrence of the 'Bükkzsérc-type' olistoliths is a special characteristic of the Bükk Mountains and has not been reported from any other Jurassic olistostromes in the western Neotethys realm. It suggests the involvement of the Bajocian platform foreslope and periplatform basin zones in the nappe accretion that took place, probably in Bathonian time.

Acknowledgements. The present work was supported by the Hungarian Science Fund (OTKA) projects K61872; K68791; F048341 and the Hantken Foundation. The authors thank the anonymous referees for their very constructive notes and suggestions. We are indebted to Henry Lieberman (Houston) for the linguistic correction of the paper.

\section{References}

Allemann, F. \& Schroeder, R. 1972. Spiroconulus perconigi n. gen. n. sp. a new Middle Jurassic foraminifer of Oman and Spain. Revista Española de Micropaleontología, Num Extraordinario 30, 199209.

AntonOva, Z. A. 1958a. Foraminifery srednej jury bassejna r. Laby. (Foraminifera of the Middle Jurassic of the Laby River Basin.) Voprosy Geologii Burenia $i$ Ekspluatatsii Skvažin, Trudy Vsesoyuznyi Neftegazovyi Nauchno-Issledovalelskii Institut (VNII), Karsnodarskij filial XVII, 41-80 (in Russian).

ANTONOVA, Z. A. 1958b. K voprosy ob evolutchii nekotorih predstavitelej oftalmidiid na primere razvitia, ih, v jurskoe vremia $\mathrm{v}$ basseine $\mathrm{r}$. Laby. (On the question of evolution of certain representatives of the Ophthalmidiidae as an example of the development in Jurassic time in the basin of the Laby River). Doklady Akademiya Nauk SSSR 122(5), 913-6 (in Russian).

Aubrecht, R., GAWLICK, H.-J., MisSONI, S., SuZUKI, H., Plašienka, D., Kronome, K. \& Kronome, B. 2010. Middle Jurassic matrix radiolarians from Meliata ophiolite melange at the type Meliatic sites Meliata 
and Jaklovce (Western Carpathians): palaeogeographic evidence. Geologica Balcanica 39(1-2), 33-4.

Auer, M., Gawlick, H.-J., SuzUKI, H. \& SchlaginTweit, F. 2009. Spatial and temporal development of siliceous basin and shallow-water carbonate sedimentation in Oxfordian Northern Calcareous Alps. Facies 55, 63-87.

Aurouze, G. \& Bizon, J. J. 1958. Rapports et différences des deux genres de foraminifers: Kilianina (Pfender) et Meyendorffina $\mathrm{n}$. gen. Revue de Micropaléontologie I(2), 67-74.

ÁRKAI, P. 1983. Very low- and low-grade Alpine regional metamorphism of sedimentary rocks of the Meliata Unit, Western Carpathians, Slovakia: implications of phyllosilicate characteristics. International Journal of Earth Sciences 92, 68-85.

ÁrKaI, P., BALOGH, K. \& DUNKL, I. 1995. Timing of lowtemperatute metamorphism and cooling of the Paleozoic and Mesozoic formations of the Bükkium, innermost West Carpathians, Hungary. Geologische Rundschau $\mathbf{8 4}$, 334-44.

BALlA, Z. 1987. Tectonics of the Bükkian (North Hungary) Mesozoic and relations to the West Carpathians and Dinarids. Acta Geologica Hungarica 30(3-4), 25787.

BALOGH, K. 1964. Die geologischen Bildungen des BükkGebirges. Annals of the Hungarian Geological Institute 48, 245-719.

Balogh, K., Kozur, H. \& Pelikán, P. 1984. Die Deckenstrukctur des Bükkgebirges. GeologishPaläaontologishe Mitteilungen Innsbruck 13, 89-96.

BANNER, F. T., Simmons, M. D. \& WhitTAKer, J. E. 1991. The Mesozoic Chrysalidinidae (Foraminifera, Textulariacea) of the Middle East: the Redmond (Aramco) taxa and their relatives. Bulletin of the British Museum Natural History (Geology) 47, 101-52.

BASSOULleT, J. P. 1997. Foraminiferes. Les grands foraminifères. In Groupe Français d'Étude du Jurassique. Biostratigraphie du Jurassique Ouest-Européen et Méditerranéen: Zonations Paralleles et Distribution des Invertébrés et Microfossiles (eds E. Cariou \& P. Hantzpergue), pp. 293-304. Bulletin des Centre de Recherche Exploration-Production Elf-Aquitaine, Mémoire 17.

Bassoullet, J. P. \& Poisson, A. 1975. Microfaciès du Jurassique de la région d'Antalya (secturs $\mathrm{N}$ et NW) Taurus Lycien (Turquie). Revue de Micropaléontologie 18(1), 3-14.

BAUMGARTNER, P. O., O'DOGHERTY, L., GORIČAN, Š., Urquhart, E., Pillevuit, A. \& De Wever, P. D. (eds) 1995. Middle Jurassic to Lower Cretaceous Radiolaria of Tethys: occurences, systematics, biochronology. Mémoires de Géologie (Lausanne) 23, 1-1162.

BECCARO, P. 2004. Upper Jurassic radiolarians from Inici Mt. Area (North-western Sicily, Italy): biochronology and calibration by ammonites. Rivista Italiana di Paleontologia e Stratigrafia 110, 289-301.

BECCARO, P. 2006. Radiolarian biostratigraphy of MiddleUpper Jurassic pelagic siliceous successions of Western Sicily and the Southern Alps (Italy). Mémoires de Géologie (Lausanne) 45, 1-120.

BÉRCZI-MAKK, A. 1999. Bükkzsérci (Észak-Magyarország) Jura rétegsorok sztratigráfiai eredményei foraminiferák alapján (Foraminiferal stratigraphy of Jurassic beds in Bükkzsérc, N-Hungary). Földtani Közlöny 116, 161-72.

BÉRCZI-MAKK, A. \& PELIKÁN, P. 1984. Jura képződmények a Bükk-hegységböl. (Jurassic formations from the Bükk Mountains). Annual Report of the Hungarian Geological Institute 1982, 137-66.
BORNEMANN, J. G. 1854. Ueber die Lias formation in der Umgegend von Göttingen und ihre organischen Einschlüsse. Dissertation Universitat Berlin, 77 pp.

Bortolotti, V., Marroni, M., PANDOlfi, L. \& PrinciPI, G. 2005. Mesozoic and Tertiary tectonic history of the Mirdita ophiolites, northern Albania. The Island Arc 14, 471-93.

Bosellini, A., MasetTI, D. \& SARTI, M. 1981. A Jurassic 'Tongue of the ocean' infilled with oolitic sands: the Belluno Trough, Venetian Alps, Italy. Marine Geology 44, 59-95.

BourRouilh, R. \& Moullade, M. 1963. Étude stratigraphique et micropaleontologique d'une série Jurassique de l'île de Minorque (Baléares, Espagne). Bulletin de la Société géologique de France V, 375-82.

BRUN, L. 1968. Etude biostratigraphique du Jurassique de la bordure atlasique nord-orientale et des plismarginaux (Maroc Oriental). In Proceedings of the Third African Micropaleontological Colloquium, 4-10 March 1968, Cairo, pp. 185-213. Cairo: The National Information and Documentation Centre (NIDOC).

BuCKOVIĆ, D. 2006. Jurassic limestones of Sošice, Žumberak Mt., Croatia; sedimentary signatures of the platform to basin transition. Acta Geologica Hungarica 49, 331-54.

Bucković, D., TeŠOvić, B. C. \& GuŠIĆ, I. 2004. Late Jurassic paleoenvironmental evolution of the Western Dinarides (Croatia). Geologica Carpathica 55, 3-18.

Chiocchini, M, \& MANCINELli, A. 1996. Archaeosepta platierensis Wernli, 1970 (Foraminiferida) from the Middle Jurassic near Mt Boragine (north-eastern Latium) and taxonomic position of the genus Archaeosepta Wernli, 1970. Palaeopelagos 6, 237-48.

Clari, P. \& MAsetTI, D. 2002. The Trento Ridge and Belluno Basin. In General Feld Trip Guide Book, VI International Symposium on the Jurassic System, Palermo, Italy (ed. M. Santantonio), pp 271-315.

ClERC, C. 2005. Les Miliolina (Foraminifères porcelanés) du Dogger du Jura méridional (France): Systématique, stratigraphie et paléoenvironnement. Ph.D. thesis, Terre \& Environnement, Université de Genève, France, These No 3599, 250 pp. Published thesis.

Crescenti, U. 1969. Biostratigrafia delle Facies Mesozoiche dell'Appennino Centrale: Correlazioni. Geologica Romana VIII, 15-40.

CREsCENTI, U. 1971. Biostratigraphic correlations in the Jurassic facies of Central Italy by means of the microfossils. Annals of the Hungarian Geological Institute 54, 209-13.

CsONTOS, L. 1988. Étude géologique d'une portion des Carpathes Internes: Le massif du Bükk (stratigraphie, structures, métamorphisme et géodinamique). Ph.D. thesis, Université de Lille Flanders-Artois, France, These No. 250, 327 pp. Published thesis.

CsONTOS, L. 2000. A Bükk-hegység mezozoos rétegtani újraértékelése. (Stratigraphic reevaluation of the Bükk Mts (Hungary)). Földtani Közlöny 130(1), 95-131.

Csontos, L., BÉrCZi-MAKK, A. \& Thiebault, F. 1991. Újabb Foraminifera-leletek a Déli-Bükkből. (Contributions to Foraminiferal fossils from the $\mathrm{S}$ part of the Bükk Mts). Annual Report of the Hungarian Geological Institute 1989, 383-409.

Csontos, L., DoszTÁLY, L. \& PelikÁN, P. 1991. Radioláriák a Bükk-hegységből. (Radiolarians from the Bükk Mts.). Annual Report of the Hungarian Geological Institute 1989, 357-81.

Csontos, L. \& Nagymarosy, A. 1998. The Mid-Hungarian line: a zone of repeated tectonic inversions. Tectonophysics 297, 57-71. 
Csontos, L., Nagymarosy, A., Horváth, F. \& Kováč, M. 1992. Tertiary evolution of the Intra-Carpathian area: a model. Tectonophysics 208, 221-41.

CsOnTOS, L. \& VÖRÖS, A. 2004. Mesozoic plate tectonic reconstruction of the Carpathian region. Palaeogeography, Palaeoclimatology, Palaeoecology 210, 1-56.

DANITCH, M. M. 1971. Miliolidy. In Mesozoic mollusks and foraminifera of the Dniester-Prut river region; ammonites and miliolids from Jurassic deposits (eds L. F. Romanov \& M. M. Danitch), pp. 85-216. Akademia Nauk Moldavskoi SSR, Otdelenie Paleontologii i Stratigraphii, Kisinev.

DERIN, B. \& REISS, Z 1965. Note on some Jurassic and Early Cretaceous Trocholina (Foraminiferida) from Israel. Oil Companies Micropaleontological Laboratory Report No. OS/1/65, $11 \mathrm{pp}$.

DiMITRIJEVIĆ, M. D. 1997. Geology of Yugoslavia. Belgrade: Geological Institute GEMINI Special Publication, $187 \mathrm{pp}$.

Dimitrijević, M. N., DimitriJević, M. D., Karamata, S., Sudar, M., Gerzina, N., Kovács, S., Dosztály, L., GulÁCSI, Z., Less, GY. \& PELIKÁN, P. 2003. Olistrotrome/mélanges - an overview of the problems and preliminary comparison of such formations in Yugoslavia and NE Hungary. Slovak Geological Magazine 9, 3-21.

DRAGIČEVIĆ, I. \& VELIĆ, I. 2002. The northeastern margin of the Adriatic Carbonate Platform. Geologica Croatica 55, 185-232.

DUFAURE, P. 1958. Contribution a l'étude stratigraphique et micropaléontologique du Jurassique et du Néocomien, de l'Aquitaine a la Provence. Revue de Micropaléontologie I(2), 87-115.

FARYAD, S. W. 1999. Metamorphic evolution of the eastern part of the Western Carpathians, with emphasis on Meliata Unit. Excursion Guide. Acta Montanistica Slovaka 4, 148-69.

FERRARI, A. 1962. Brachiopodi giurassici dei dintori di Rovereto (Trentino). Giornale de Geologica, Series $2 a$ 29(1960/61), 91-153.

Filipović, I., Jovanović, D., Sudar, M., PelikÁn, P., KovÁCs, S., LESS, GY. \& HIPS, K. 2003. Comparison of the Variscan-Early Alpine evolution of the Jadar Block (NW Serbia) and 'Bükkium' (NE Hungary) terranes; some paleogeographic implications. Slovak Geological Magazine 9, 3-21.

Fodor, L., MÁrton, E., Jelen, B., BÁldi-BeKe, M., KÁzMÉr, M., \& RifELJ, H. 1999. Connection of the eastern Periadriatic and Mid-Hungarian zones and its implication to Paleogene paleogeography, Miocene extrusion tectonics. Tübinger Geowissenschaftliche Arbeiten Series A 52, 141-2.

FRANKE, A. 1936. Die Foraminiferen des deutschen Lias. Abhandlungen der Preussischen Geologischen Landesanstalt, Neue Folge 169, 138 pp.

GaWlick, H.-J, Frisch, W., HOXHA, L., DumitricA, P., Krystyn, L., Lein, R., Missoni, S. \& SchlagintWEIT, F. 2008. Mirdita Zone ophiolites and associated sediments in Albania reveal Neotethys Ocean origin. International Journal of Earth Sciences 97, 865-81.

GAWLICK, H.-J., SUDAR, M., SUZUKI, H., DERIĆ, N., Missoni, S., Lein, R. \& Jovanović, D. 2009. Platetectonic Upper Triassic and Middle Jurassic radiolarians from the ophiolitic mélange of the Dinaridic Ophiolite Belt, SW Serbia. Neues Jahrbuch für Geologie und Paläontologie, Abhandlungen 253, 293-311.

GORIČAN, Š. 1994. Jurassic and Cretaceous radiolarian biostratigraphy and sedimentary evolution of the Budva
Zone (Dinarides, Montenegro). Mémoires de Géologie (Lausanne) 18, 1-120.

Goričan, Š., Karamata, S. \& BAToĆANIN-SREĆKOVIĆ, D. 1999. Upper Triassic (Carnian-Norian) radiolarians in cherts of Sjenica and the time span of the oceanic realm ancestor of the Dinaric Ophiolite Belt. Bulletin de l'Académie Serbe des Sciences et des Arts, CXIX Classe 39, 141-49.

GuŠIĆ, I. 1969. Some new and inadequately known Jurassic foraminifers from central Croatia. Geološki Vjesnik 22, $55-88$.

GuTNIC, M. \& Moullade, M. 1967. Données nouvelles sur le Jurassique et le Crétacé inférieur du Barla Dağ au sud de senirkent (Taurus de Pisidie, Turquie). Bulletin of the Mineral Research and Exploration Institute Turkey 69, 60-78.

HAAs, J., GÖRÖG, Á., KovÁcs, S., OzSvÁrT, P., MATYÓK, I. \& PELIKÁN, P. 2006. Displaced Jurassic foreslope and basin deposits of Dinaridic origin in Northeast Hungary. Acta Geologica Hungarica 49, 12563.

HAAS, J. \& KovÁCS, S. 2001. The Dinaridic-Alpine connection - as seen from Hungary. Acta Geologica Hungarica 44, 345-62.

HAAS, J., KOVÁCS, S., KARAMATA, S., SUdAR, M., GAWLICK, H.-J., GrĂdinaru, E., Mello, J., PolÁK, M., PÉrÓ, CS., OGORELEC, B. \& BUSER, S. 2010. Jurassic environments in the Circum-Pannonian region. In Variscan and Alpine Terranes of the Circum-Pannonian Region (eds J. Vozár, F. Ebner, A. Vozarová, J. Haas, S. Kovács, M. Sudar, M. Bielik. \& Cs. Péró), pp. 157-202. Bratislava: Slovak Academy of Sciences, Geological Institute.

HaAs, J., Kovács, S., PelikÁn, P., Kövér, Sz., GÖröG, Á., Ozsvárt, P., JÓzSA, S. \& NÉMETH, N. 2011. A Neotethys-óceán akkréciós komplexumának maradványai Észak-Magyarországon. (Remnants of the accretionary complex of the Neotethys Ocean in Northern Hungary.) Földtani Közlöny 141, 412-66.

HaAs, J., Mioč, P., PAMić, J., TOMLJEnOvić, B., Árkai, P., Bérczi-MaKK, A., Koroknai, B., Kovács, S. \& RÁlisch-FelgenHAUER, E. 2000. Complex structural pattern of the Alpine-Dinaridic-Pannonian triple junction. International Journal of Earth Sciences 89, 377 89.

Halamić, J., Goričan, Š., Slovenec, D. \& KolaRJURKOVŠEK, T. 1999. A Middle Jurassic radiolariteclastic succession from the Medvednica Mt. (NW Croatia). Geologica Croatica 52, 29-57.

HALAMIĆ, J., MARCHIG, V. \& GORIČAN, Š. 2005. Jurassic radiolarian cherts in north-western Croatia: geochemistry, material provenance and depositional environment. Geologica Carpathica 5, 123-36.

HeINZ, R. A. \& ISENSCHMID, CH. 1988. Mikrofazielle und stratigraphische Untersuchungen im Massivkalk (Malm) der Préalpes médianes. Eclogae Geologicae Helvetiae 81(1), 1-62.

HENSON, F. R. S. 1948. Foraminifera of the Genus Trocholina in the Middle East. Annals and Magazine of Natural History 14(12), 445-59.

HiPs, K. \& PELIKÁN, P. 2002. Lower Triassic shallow marine succession in the Bükk Mountains, NE Hungary. Geologica Carpathica 53(6), 351-67.

KARAMATA, S. 1985. Metamorphism in the contact aureole of Berzovica (Serbia, Yugoslavia) as a model of metamorphism beneath obducted hot ultramafic bodies. Bulletin de l'Académie Serbe des Sciences et des Arts, CXI, Classe des Sciences Mathématiques et NaturellesSciences Naturelles, Belgrade 26, 51-8. 
KARAmATA, S. 2006. The geological development of the Balkan Peninsula related to the approach, collision and compression of Gondwanan and Eurasian units. In Tectonic Development of the Eastern Mediterranean Region (eds A. H. F. Robertson \& D. Mountrakis), pp. 155-78. Geological Society of London, Special Publication no. 260.

Karamata, S., Dimitrijević, M. D., Dimitrijević, M. N. \& Milovanović, D. 2000. A correlation of ophiolitic belts and oceanic realms of the Vardar Zone and the Dinarides. In Proceedings of the International Symposium 'Geology and Metallogeny of the Dinarides and the Vardar Zone' (eds S. Karamata \& S. Janković), pp. 191-204. The Academy of Sciences and Arts of the Republic of Srpska, Department of Natural, Mathematical and Technical Sciences, Collections and Monographs I.

KAssimova, G. K. 1971. The stratigraphic importance of miliolids in the Jurassic deposits of Azerbaidzhan. Izvestiya Akademiya Nauk Azerbaydzhanskoy SSR, Seriya Nauk o Zemle 1971(5-6), 3-9.

Kiss, G., MolnÁr, F., KovÁCS, S. \& Palinkaš, L. A. 2010. Field characteristics and petrography of the advanced rifting-related Triassic submarine basaltic blocks in the Jurassic mélange of the Darnó Unit. Central European Geology, 53, 181-204.

Kiss, G., MolnÁR, F. \& PAlinkaš, L. A. 2008. Volcanic facies and hydrothermal processes in Triassic pillow basalts from Darnó Unit, NE Hungary. Geologica Croatica 61, 385-94.

KoEHn-ZANINETTI, L. \& BRÖNNIMANN, P. 1968. Triasina oberhauseri, n. sp., un Foraminifére nouveau de la Dolomie principale des Alpes Calcaires septentrionales (Autriche). Institut de Paléontologie, Université de Genève, $6 \mathrm{pp}$.

Kovács, I., Csontos, L., Szabó, Cs., Bali, E., Falus, Gy., BenedeK, K. \& ZAJACZ, Z. 2007. PaleogeneEarly Miocene igneous rocks and geodynamics of the Alpine-Carpathian-Pannonian-Dinaric region: an integrated approach. Geological Society of America, Special Paper 418, 93-112.

KovÁcs, S. \& HAAS, J. 2010. Displaced South Alpine and Dinaridic elements in the Mid-Hungarian Zone. Central European Geology 53, 135-64.

KöVÉr, SZ., HAAS, J., GÖRÖG, Á., JÓZSA, S., OZSVÁRT, P. \& GöTZ, A. 2009. Lithofacies characteristics and new age data from the uppermost Triassic-Jurassic foreslope and basin sediments of Rudabánya Hills, NE Hungary. Geologica Carpathica 60, 351-79.

KozUR, H. 1984. New radiolarian taxa from the Triassic and Jurassic. Geologisch-Paläontologische Mitteilungen Innsbruck 13, 49-88.

KozUR, H. \& Mock, R. 1995. New biostratigraphic results in the Meliaticum of Slovakia, their tectonic and paleogeographic significance. Program and Abstracts, International Earth Science Colloquium on the Aegean Region 1995, Izmir, Turkey, 34-5.

Kozur, H., Mock, R. \& Ožvoldová, L. 1996. New biostratigraphic results in the Meliaticum in its type area around Meliata village (Slovakia) and their tectonic and paleogeographic significance. GeologischPaläontologische Mitteilungen Innsbruck 21, 89-121.

LuCAS, G. 1939. Dictyoconus cayeuxi n. sp. foraminifère de grande taille de l'Aalénien de l'Oranie occidentale. Compte Rendu Sommaire de la Société géologique de la France 15, 353-5.

MATSUOKA, A. 1984. Late Jurassic four-segmented nassellarians (Radiolaria) from Shikoku, Japan. Journal of Geosciences, Osaka City University 27, 14353.

Missoni, S., Gawlick, H. J., Suzuki, H. \& Diersche, V. 2005. Die paläogeographische Stellung des Watzmann Blockes in den Berchtesgadener Kalkalpen - Neuergebnisse auf der Basis der Analyse der Trias- und JuraEntwicklung. Journal of Alpine Geology 47, 169209.

MizUTANI, S. \& KIDO, S. 1983. Radiolarians in Middle Jurassic siliceous shale from Kamiaso, Gifu Prefecture, central Japan. Transactions and Proceedings of the Palaeontological Society of Japan, New series 132, 253 62.

Mock, R., SÝkora, M., Aubrecht, R., OžvoldovÁ, L., KRONOME, B., REICHWALDER, P. \& JABLONSKÝ, J. 1998. Petrology and stratigraphy of the Meliaticum near the Meliata and Jaklovce Villages, Slovakia. Slovak Geological Magazine 4, 223-60.

MOHLER, W. 1938. Mikropaläontologische Untersuchungen in nordschweizerischen Juraformation. Abhandlungen der Schweizerischen paläontologischen Gesellschaft $\mathbf{6 0}$, $1-53$.

OBERHAUSER, R. 1957. Ein Vorkommen von Trocholina und Paratrocholina in der ostalpinen Trias. Jahrbuch der Geologischen Bundesansalt, Wien 100(2), 257-67.

OBERHAUSER, R. 1964. Zur Kenntnis der Foraminiferengattungen Permodiscus, Trocholina und Triasina in der alpinen Trias und ihre Einordnung zu den Archaedisciden. Verhandlungen der Geologischen Bundesanstalt 2, 196-210.

O'Dogherty, L., BILl, M., GoriČAn, Š., DuMitriCA, P. \& MASSON, H. 2005. Bathonian radiolarians from an ophiolitic mélange of the Alpine Tethys (Gets Nappe, Swiss-French Alps). Micropaleontology 51, 425-85.

OžVOLDOVA, L. 1975. Upper Jurassic radiolarians from the Kisuca Series in the Klippen Belt. Zápádné Karpaty, Séria Paleontológia 1, 73-86.

PAZDROWA, O. 1959. On the stratigraphic distribution of Miliolidae in the Middle Jurassic of Poland. Acta Geologica Polonica 9, 345-82.

PAMić, J. 1997. The northwesternmost outcrops of the Dinaridic ophiolites: a case study of Mt. Kalnik (North Croatia). Acta Geologica Hungarica 40(1), 37-56.

PAMIĆ, J. 2003. The allochthonous fragments of the Internal Dinaridic units in the western part of the South Pannonian Basin. Acta Geologica Hungarica 46(1), 4162.

Pamić, J., TomlJenović, B. \& BALEN, D. 2002. Geodynamic and petrogenetic evolution of Alpine ophiolites from the Central and NW Dinarides: An overview. Lithos 65, 113-42.

PELIKÁN, P. 1987. Section Lök-völgy 2. Felsőtárkány, Bükk Mts. Geological Key-sections of Hungary. Budapest: MÁFI, 5 pp (in Hungarian).

PelikÁn, P. 2005. Mezozoikum. (Mezozoic). In A Bükk Hegység Földtana. Geology of the Bükk Mountains (eds P. Pelikán \& T. Budai), pp. 45-92. Budapest: MÁFI

PELIKÁN, P. \& DOSZTÁLY, L. 2000. Jurassic formations of the Bükkzsérc boreholes (SW Bükk Mts, NE Hungary) and their structural setting. Földtani Közlöny 130(1), 25-46.

PESSAgnO, E. A. 1977. Upper Jurassic Radiolaria and radiolarian biostratigraphy of the California Coast Ranges. Micropaleontology 23(1), 56-113.

Pessagno, E. A., Blome, C., Hull, D. M. \& Six, W. M. 1993. Jurassic Radiolaria from the Josephine ophiolite and overlying strata, Smith River subterrane (Klamath Mountains), northwestern California and southwestern Oregon. Micropaleontology 39(2), 93-166. 
PfEndER, J. 1933. Sur un foraminifère nouveau du Bathonien des Montagnes d'Escreins (Haut-Alpes): Kilianina blancheti, gen, nov. n. sp. Annales de l'Université de Grenoble, Section Sciences-Médecine 10, 243-52.

Protić, L., Filipović, I., PelikÁn, P., Jovanović, D., Kovács, S., SudAR, M., HiPs, K., Less, Gy. \& CVIJÍ́, R. 2000. Correlation of the Carboniferous, Permian and Triassic sequences of the Jadar Block, SanaUna and 'Bükkium' Terranes. In Proceedings of the International Symposium on Geology and Metallogeny of the Dinarides and Vardar Zone (eds S. Karamata \& S. Janković), pp. 61-9. Banja Luka.

RADOIČIČ, R. 1966. Microfacies du Jurassique des Dinarides externes de la Yougoslavie. Geological Transactions and Reports 9(9), 5-377.

RADOIČIČ, R. 1987. Spiraloconulus perconigi Allemann \& Schroeder (Foraminifera) in some Jurassic series of Yugoslavia, Greece and Iraq. Geoloski Glasnik XII, 117-25.

RAFFI, G. \& FORTI, A. 1959. Micropaleontological and stratigraphical investigations in 'Montagna del Morrone' (Abruzzi-Italy). Revue de Micropaléontologie 2(1), 820.

RoBERTSON, A., KARAMATA, S. \& ŠArić, K. 2009. Overview of ophiolites and related units in the Late PalaeozoicEarly Cenozoic magmatic and tectonic development of Tethys in the northern part of the Balkan region. Lithos 108, 1-36.

Robertson, A. \& SAllo, M. 2000. Mesozoic-Tertiary tectonic evolution of Albania in its regional Eastern Mediterranean context. Tectonophysics 316, 197-254.

RožIČ, B. 2009. Perbla and Tolmin formations: revised Toarcian to Tithonian stratigraphy of the Tolmin Basin (NW Slovenia) and regional correlations. Bulletin de la Société géologique de France 180, 411-30.

RožIČ, B. \& POPIT, T. 2006. Redeposited limestones in the Middle and Upper Jurassic successions of Slovenian basin. Geologija 49(2), 219-34.

RUGGIERI, G. \& GIUNTA, G. 1965. Microfacies a spirilline nel Dogger dei dintorni di Trapani. Atti Societi Toscana Scienze Naturali, Sene A 72(2), 399-413.

RÜST, D. 1885. Beiträge zur Kenntniss der fossilen Radiolarien aus Gesteinen des Jura. Palaeontographica 31, 269-321.

SASHIDA, K. 1988. Lower Jurassic multisegmented Nasselaria from the Itsukaichi area, western part of Tokyo Prefecture, central Japan. Science Reports of the Institute of Geosciences, University of Tsukuba, section B 9, 127.

SASHidA, K., MunAsRi, S., AdACHI, S. \& KAMATA, Y. 1999. Middle Jurassic radiolarian fauna from Rotti Island, Indonesia. Journal of Asian Earth Sciences 17, 561-72.

SCHLUMBERGER, C. 1898 Note sur Involutina conica n. sp.. Feuille des Jeunes Naturalistes 28(1897-1898), 150-1.

SCHMid, S. M., BERNOUlli, D., FÜGENSCHUH, B., MATENCO, L., Schuster, R., Schefer, S., Tischler, M., \& UstaszewsKi, K. 2008. The Alpine-CarpathianDinaridic orogenic system: correlation and evolution of tectonic units. Swiss Journal of Geosciences 101, 13983.

SCHRÉTER, Z. 1959. A Bükk-hegység tengeri eredetü permi képződményei. (Formations of marine origin of the Bükk Mountains.) Földtani Közlöny 89, 364-73.

Septfontaine, M. 1974. Présence de Protopeneroplis trochangulata sp. nov. (Foraminifère) dans Crétacé inférieur du Jura méridional et révision de Protopeneroplis Weynschenk, 1950. Eclogae Geologicae Helvetiae 67(3), 605-28.
SePtFontaine, M. 1977. Niveaux a Foraminifères (Pfenderininae et Valvulininae) dans le Dogger des Préalapes médianes du Chablais occidental (HauteSavoie, France). Eclogae Geologicae Helvetiae 70, 599625.

SePtFontaine, M. 1978. Présence d'Archaeosepta platierensis Wernli, 1970 dans le Jurassique briançonnais des Préalapes. Importance stratigraphique; relation avec le microfacies et la paléogéographie. Note du Laboratoire de Paléontologie de l'Université de Genève 1, 1-6.

SEPTFONTAINE, M. 1981. Les foraminifères imperforés des milieux de plate-forme au Mésozoique: détermination pratique, interprétation phylogénétique et utilisation biostratigraphique. Revue de Micropaléontologie 23(3/4), 169-203.

SOTAK, J. 1987. Protopeneroplidae foraminifers from the lowermost Cretaceous of the Stramberk carbonate platform (Outer Western Carpathians). Geologica Carpathica 38, 631-67.

Spray, J. G., Bebien, J., ReX, D. C. \& Roddick, J. C. 1984. Age constraints on the igneous and metamorphic evolution of the Hellenic-Dinaric ophiolites. In The Geological Evolution of the Eastern Mediterranean (eds J. E. Dixon \& A. H. F. Robertson), pp. 619-27. Geological Society of London, Special Publication no. 17.

Stampfli, G. M., Borel, G. D., Cavazza, W., Mosar, J. \& ZIEGLER, P. A. 2001. The Paleotectonic Atlas of the Peritethyan Domain, CD-ROM. European Geophysical Society.

SUZUKI, H. \& GAWLICK, H. J. 2003. The Jurassic radiolarian zones of the Northern Calcareous Alps. In Beiträge zur Geologie des Salzkammerguts (eds J. T. Weidinger, H. Lobitzer \& I. Spitzbart), pp. 115-22. Gmundner GeoStudien 2.

SuZuKI, H. \& OGANE, K. B. 2004. Paleoceanographic affinities of radiolarian faunas in late Aalenian time (Middle Jurassic) recorded in the Jurassic accretionary complex of Japan. Journal of Asian Earth Sciences 23, 343-57.

Terquem, M. O. \& Berthelin, G. 1875. Étude microscopique des marnes du Lias moyen d'Essey-Les-Nancy, zone inférieure de l'assisi à Ammonites margaritatus. Mémoires de la Société Géologique de France 10(2), $1-126$.

TiŠlJar, J., Vlahović, I., Velić, I. \& SOKaČ, B. 2002. Carbonate platform megafacies of the Jurassic and Cretaceous deposits of the Karst Dinarides. Geologia Croatica 55(2), 139-70.

VELIĆ, I. 2007. Stratigraphy and palaeobiogeography of Mesozoic benthic foraminifera of the Karst Dinarides (SE Europe). Geologica Croatica 60(1), 1-113.

VELLEDITS, F. 2000. A Berva-völgytől a Hór-völgyig terjedö terület fejlődéstörténete a középső-felső triászban. (Evolution of the area from the Berva Valley to the Hór Valley in the Middle-Upper Triassic). Földtani Közlöny 130, 47-93.

VishneVSKAYA, V., DERIĆ, N. \& ZAKARIADZE, G. S. 2009. New data on Mesozoic Radiolaria of Serbia and Bosnia and implications for age and evolution of oceanic volcanics of Central and Northern Balkanides. Lithos 108, 72-105.

WAKITA, K. 1988. Origin of chaotically mixed rock bodies in the Early Jurassic to Early Cretaceous sedimentary complex of the Mino terrane. Geological Survey of Japan Bulletin 39, 675-757.

WERNLI, R. 1970. Archaeosepta platierensis Wernli n. gen. n. sp., un nouveau foraminifère du Dogger du Jura 
méridional. Compte Rendus des Séances, SPHN Genève 5(1), 87-93.

WERNLI, R. \& METZGER, J. 1990. Callorbis minor, n.g., n.sp., un nouveau foraminifère des calcaires échinodermiques du Bajocien du Jura (France). Eclogae Geologicae Helvetiae 83(1), 163-75.

WEYNSCHENK, R. 1950. Die Jura-Mikrofauna und -flora des Sonnwendgebirges (Tirol). Univ. Innsbruck, Austria. Schlern-Schriften 83, 1-32.
WIDZ, D. \& DE Wever, P. 1993. Nouveaux Nassellaires (Radiolaria) des radiolarites Jurassiques de la coupe de Szeligowy Potok (Zones de Klippes de Pieniny, Carpathes Occidentales, Pologne). Revue de Micropaléontologie 36(1), 77-91.

YAO, A. 1979. Radiolarian fauna from the Mino Belt in the northern part of the Inuyama Area, Central Japan, Part II: Nassellaria 1. Journal of Geosciences, Osaka City University 22, 21-72. 